\title{
MiR-21: an environmental driver of malignant melanoma?
}

\author{
Bodo C Melnik
}

\begin{abstract}
Since the mid-1950's, melanoma incidence has been rising steadily in industrialized Caucasian populations, thereby pointing to the pivotal involvement of environmental factors in melanomagenesis. Recent evidence underlines the crucial role of microRNA (miR) signaling in cancer initiation and progression. Increased miR-21 expression has been observed during the transition from a benign melanocytic lesion to malignant melanoma, exhibiting highest expression of miR-21. Notably, common BRAF and NRAS mutations in cutaneous melanoma are associated with increased miR-21 expression. MiR-21 is an oncomiR that affects critical target genes of malignant melanoma, resulting in sustained proliferation (PTEN, PI3K, Sprouty, PDCD4, FOXO1, TIPE2, p53, cyclin D1), evasion from apoptosis (FOXO1, FBXO11, APAF1, TIMP3, TIPE2), genetic instability (MSH2, FBXO11, hTERT), increased oxidative stress (FOXO1), angiogenesis (PTEN, HIF1 $\alpha$, TIMP3), invasion and metastasis (APAF1, PTEN, PDCD4, TIMP3). The purpose of this review is to provide translational evidence for major environmental and individual factors that increase the risk of melanoma, such as UV irradiation, chemical noxes, air pollution, smoking, chronic inflammation, Western nutrition, obesity, sedentary lifestyle and higher age, which are associated with increased miR-21 signaling. Exosomal miR-21 induced by extrinsic and intrinsic stimuli may be superimposed on mutation-induced miR-21 pathways of melanoma cells. Thus, oncogenic miR-21 signaling may be the converging point of intrinsic and extrinsic stimuli driving melanomagenesis. Future strategies of melanoma treatment and prevention should thus aim at reducing the burden of miR-21 signal transduction.
\end{abstract}

Keywords: Environment, Exosome, Inflammation, Melanoma, Milk, MiR-21, Obesity, Pollution, UV-irradiation, Western lifestyle

\section{Background}

In developed countries, melanoma incidence has been rising with an annual increase between 3 and $7 \%$ for Caucasians since the mid-1950's [1]. Thus, epidemiological data clearly point to the involvement of environmental factors in melanomagenesis. Lifestyle factors including occupational exposure, Western style nutrition, obesity, increased body mass index (BMI), recreational sun exposure, tanning and reduced physical activity may explain the relationship between environmental and socioeconomic factors and malignant cutaneous melanoma [2]. Recent data suggest that the common BRAF(V600E) mutation detected in melanoma is not associated with

*Correspondence: melnik@t-online.de

Department of Dermatology, Environmental Medicine and Health Theory,

University of Osnabrück, Sedanstrasse 115, 49090 Osnabrück, Germany chronic sun exposure [3]. Thus, other environmental and epigenetic factors may play a role in melanomagenesis. Significant changes of microRNA (miR) expression in response to environmental exposure of humans have recently been reported [4]. MiRs are important posttranscriptional regulators controlling more than $30 \%$ of human mRNAs. Certain miRs such as miR-21 function as potent oncogenes [5] and play an important role in the initiation and progression of cancer [6]. OncomiRs affect all seven hallmarks of malignant cells: (1) self-sufficiency in growths signals, (2) insensitivity to anti-growth signals, (3) evasion from apoptosis, (4) limitless replicative potential, (5) angiogenesis, (6) invasion and metastasis, and (7) inflammation [6]. Current melanoma research focuses on the contribution of miR dysregulation in malignant melanoma [7-9] and its relation to BRAF and NRAS oncogenic mutations [10-12]. 
MiR-21 is highly expressed in melanoma cells and apparently plays a pivotal role in melanomagenesis [13]. A steady increase of miR-21 expression has been detected from benign to borderline melanocytic lesions and to primary cutaneous melanomas exhibiting an 8.6-fold overexpression of miR-21 [14]. UV-irradiation stimulates miR-21 expression in the skin [15]. Westernized nutrition, air pollution and inflammation all increase miR-21 signaling $[4,16,17]$. This review by means of translational research presents an analysis of the potential role of environmental and intrinsic factors that are associated with increased miR-21 expression and highlights miR-21-dependent pathways that may synergize in driving initiation and progression of malignant melanoma.

\section{MiR-21 and malignant melanoma}

MiR-21 is a key oncogene, which is highly expressed in most cancers $[18,19]$. Critical targets of miR-21 are mRNAs of tumor suppressor proteins, checkpoint regulators of cell cycle control, and intrinsic and extrinsic pathways of cellular apoptosis [20]. MiR-21 inhibits mRNA expression of crucial tumor suppressor proteins such as PTEN (phosphatase and tensin homolog) $[21,22]$, Sprouty1 and Sprouty2 [23-25], and PDCD4 (programmed cell death protein 4) [26-29]. MiR-21 is a negative regulator of p53 signaling [30] and stimulates the expression of the cell cycle promoter cyclin D1 [31]. MiR-21 induces tumor angiogenesis through targeting
PTEN, leading to activated AKT and ERK1/2 signaling, thereby enhancing hypoxia-inducible factor $1 \alpha$ (HIF $1 \alpha)$ and the expression of the vascular endothelial growth factor (VEGF) [32]. HIF1 $\alpha$ is a crucial downstream target of miR-21 in regulating tumor angiogenesis [32-34]. Overexpression of HIF $1 \alpha$ and HIF $2 \alpha$ is linked to VEGF expression and poorer prognosis in malignant melanomas [35, 36] (Figure 1).

APAF1, apoptotic protease activating factor-1, which is the molecular core of the apoptosome, has been identified as a miR-21 target [37]. Metastatic melanomas often lose APAF1, a cell-death effector that acts with cytochrome $\mathrm{c}$ and caspase-9 to mediate p53-dependent apoptosis [38, 39]. There is an inverse correlation between APAF1 expression and melanoma progression $[40,41]$. In fact, a significant difference in APAF1 mRNA expression between melanomas of Breslow thickness $<1$ and $>4 \mathrm{~mm}$ has been detected [41]. Thus, there is good reason to believe that increased miR-21 expression via suppression of APAF1 prevents apoptosis in melanoma. Further studies confirm the involvement of miR-21 in the pathogenesis, carcinogenesis, progression and metastasis of malignant melanoma [13, 14, 42-45].

Mutations in the BRAF gene and less frequently such as PTEN, KIT, CDK4, p53, MDM2, cyclin D1, AKT3, $\mathrm{PI} 3 \mathrm{~K} \alpha$, or NRAS are involved in melanoma progression [10-12]. Important negative regulators of NRAS/BRAF/ MEK/ERK- and the PI3K/AKT/mTORC1 signaling pathways are targets of miR-21 (Figure 2). Sprouty proteins

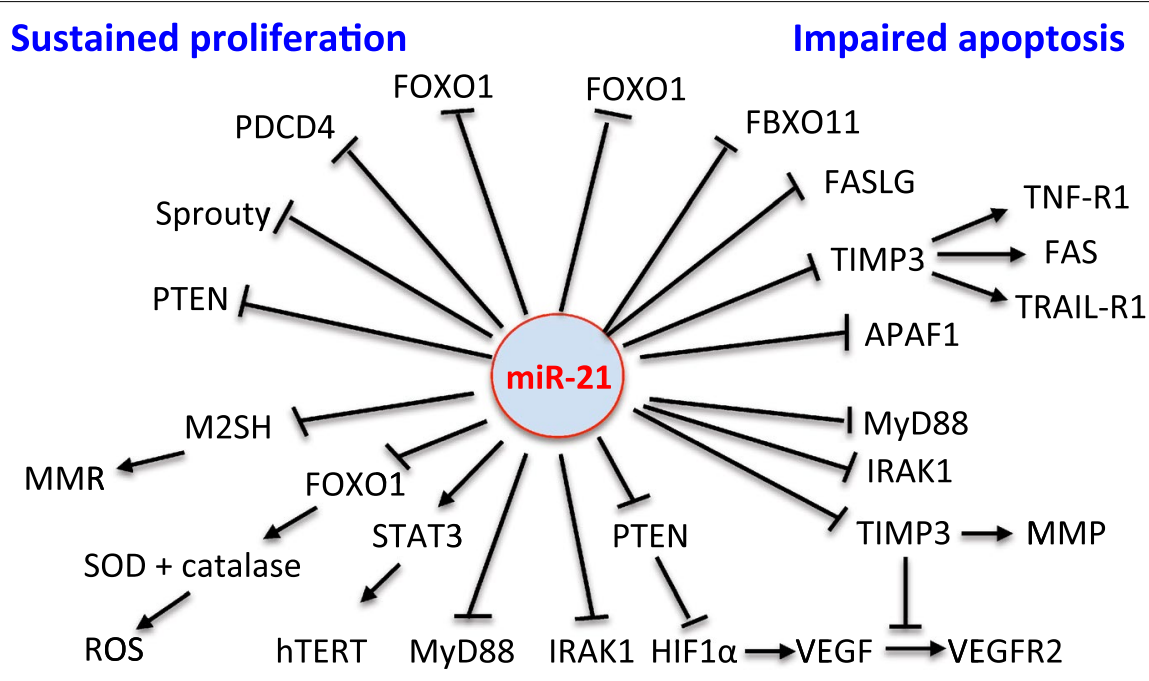

\section{Genetic instability Inflammation Angiogenesis, Invasion, Immunosuppression}

Figure 1 MiR-21 target mRNAs with potential impact on melanomagenesis. MiR-21 affects all major hallmarks of cancer: sustained proliferation, impaired apoptosis, genetic instability, angiogenesis and invasion, and inflammation (see list of abbreviations). 


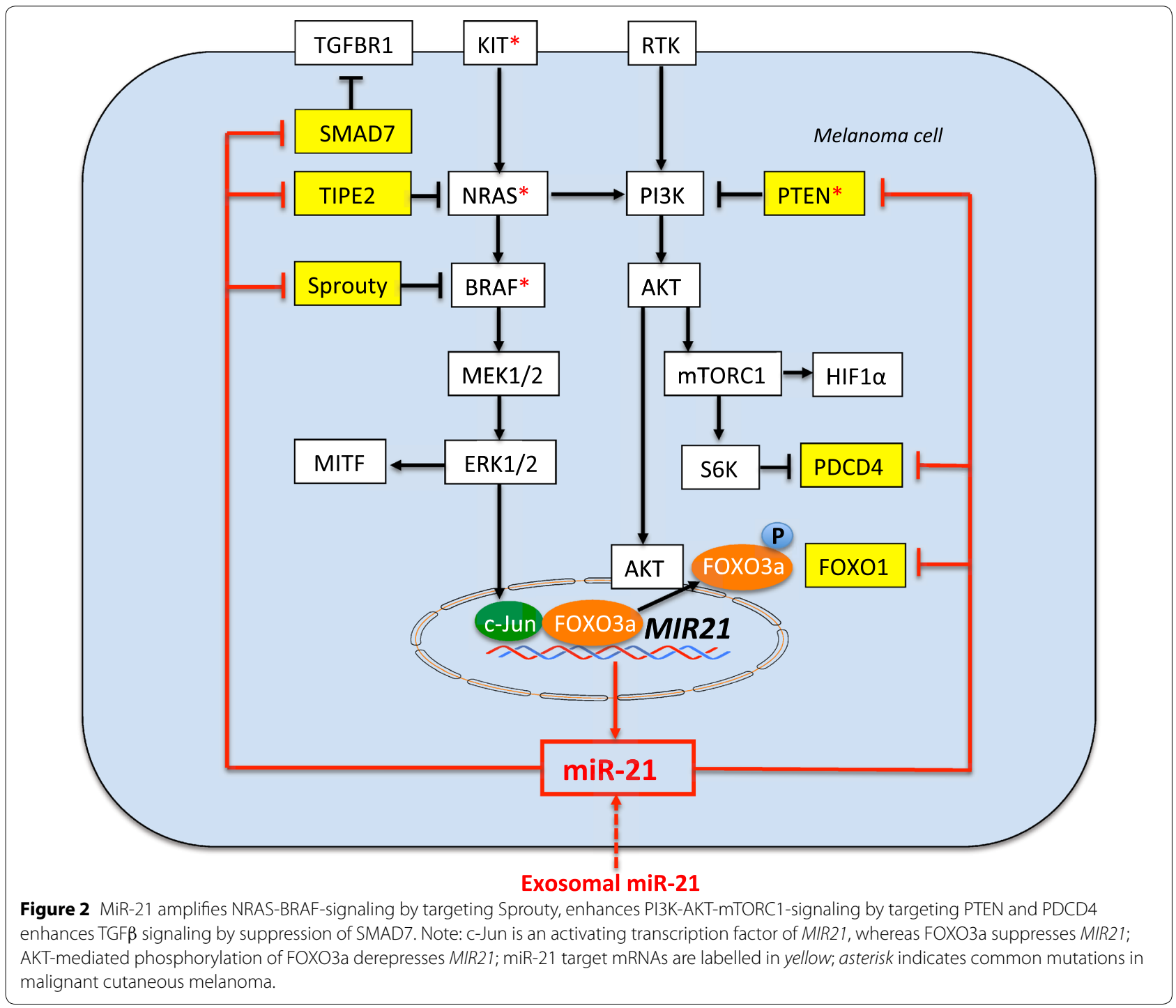

are negative master regulators of RAF-RAS signaling [46]. MiR-21-mediated inhibition of Sprouty may thus promote mutated BRAF/NRAS signaling of melanoma cells. MiR-21 augments PI3K/AKT/mTORC1 signaling in cancer cells at various levels of the pathway [47, 48]. Recent evidence suggests that miR-21-mediated gene regulation interconnects with the AKT pathway [48]. In PC3 cells, miR-21 expression resulted in a dramatic increase in basal levels of the PI3K subunit p85 [49]. PI3K signaling is required for TGF $\beta$-induced epithelial-mesenchymal (EMT)-like transition in human melanoma cells [50].

PTEN, which suppresses PI3K/AKT signaling, is often mutated in melanomas $[12,51]$. Inactive mutated PTEN leads to overactivation of AKT, which inactivates FOXO tumor suppressor proteins [52].
Recent evidence shows that miR-21 not only targets PTEN, but also FOXO1 mRNA [53, 54]. Decreased FOXO activity has been associated with the malignant phenotype of melanoma cells $[55,56]$. FOXO3a stimulates apoptosis by negatively targeting miR-21 [57]. MiR21 suppresses the translation of pro-apoptotic FAS ligand (FASLG) [57]. It is noteworthy to mention that FoxO3a is a transcription factor promoting FOXO1 upregulation [58]. Thus, there exists a transcriptional and posttranslational regulatory network between FOXO3a, FOXO1 and miR-21 expression. Nuclear activity of FOXO transcription factors depends on PI3K/AKT-mediated phosphorylation of FOXO proteins [59]. As the miR-21 target PTEN counteracts the activity of PI3K, miR-21 has an upstream influence on nuclear FOXO-mediated transcription such as the expression of FOXO-dependent 
target genes like FASLG, cyclin D1, p21, superoxide dismutase and catalase involved in the regulation of apoptosis, cell cycle progression and defense against reactive oxygen species (ROS) [60]. Taken together, miR-21 enhances upstream and downstream PI3K/AKT signaling and reduces FOXO activities.

PDCD4 is a negative regulator of translation and acts as a tumor suppressor [61]. Notably, mTORC1 stimulates mRNA translation and protein synthesis via S6K1-mediated phosphorylation of PDCD4 (Figure 2) [62]. PDCD4 is suppressed in $\sim 25 \%$ of human cell lines that are established from advanced melanoma lesions [63]. PDCD4 is a target of miR-21 [26-29]. Thus, overexpression miR21 is involved in EMT by targeting PDCD4 and PTEN [64-67].

BTG2 (B-cell translocation gene 2) encodes an antiproliferative protein involved in the regulation of the G1/S transition of the cell cycle [68]. The tumor suppressor BTG2 is relevant to cell cycle control and cellular response to DNA damage [69]. BTG2 acts as a major downstream effector of p53-dependent proliferation arrest of mouse and human fibroblasts transduced with oncogenic RAS [70]. BTG2 is a known target of miR21 [71]. Knockdown of miR-21 in B16 melanoma cells increases BTG2 levels [42], indicating that BTG2 is a miR-21 target in melanoma cells.

Another recently identified target of miR-21 is the insulin-like growth factor binding protein 3 (IGFBP3) [72]. Along with having a number of IGF-independent effects on cell growth and survival, IGFBP3 is known to modulate the activity of insulin-like growth factors (IGFs) [73]. In glioblastoma, miR-21-mediated downregulation of IGFBP3 expression promotes tumorigenesis [72]. Recent evidence underscores that IGFBP3 exerts a specific inhibitory effect on melanoma growth and dissemination [74].

Recently, the tumor suppressor FBXO11 has been identified as a novel miR-21 target [75]. FBXO11 is a component of the SKP1-CUL1-F-box ubiquitin ligase complex that targets proteins for ubiquitination and proteasomal degradation [76], a regulatory mechanism that plays a crucial role in the maintenance of genome stability [77]. FBXO11 promotes apoptosis by mediating the degradation of oncogenic BCL6. Notably, FBXO11 acts as a tumor suppressor in melanoma and has been shown to regulate apoptosis of B10BR mouse melanocytes [78].

Another recently detected miR-21 target is the tissue inhibitor of metalloproteinases 3 (TIMP3) [79]. Increased miR-21 expression enhances the invasive potential of melanoma cell lines through TIMP3 inhibition by (1) increasing matrix metalloproteinase activity [80], (2) by stimulating angiogenesis via TIMP3-mediated blockade of VEGF binding to VEGFR2 [80], and (3) by attenuating TIMP3-mediated apoptosis. Notably, TIMP3 exhibits potent antitumor activity in an animal model of melanoma [81] and induces apoptosis in melanoma cells [82]. Adenovirally expressed TIMP3 stabilzes tumor necrosis factor receptor-1 (TNF-R1), FAS, and TNF-related apoptosis, inducing ligand receptor-1 (TRAIL-R1) on melanoma cell surface, sensitizing these cells to apoptosis induced by TNF- $\alpha$, anti-FAS-antibody and TRAIL [83]. Thus, the miR-21 target TIMP3 promotes apoptosis in melanoma cells by stabilizing three distinct death receptors and activating their apoptotic signaling cascade through caspase-8 (Figure 1).

Integrin- $\beta 4$ (ITG $\beta 4$ ) is a novel miR-21 target gene and plays a role in the regulation of EMT, as it is remarkably derepressed after transient miR-21 silencing and downregulated after miR-21 overexpression. MiR-21-dependent changes of ITG 44 expression significantly affect cell migration properties of colon cancer cells [84].

Expression of the L1 cell adhesion molecule (L1CAM) frequently occurs in human cancers and is associated with poor prognosis in cancers. It has recently been demonstrated that L1CAM induces the motility of B16F10 melanoma cells via the activation of MAPK pathways [85]. Notably, miR-21-3p has been identified as a positive regulator of L1CAM expression [86].

Overexpression of tropomyosin 1 (TPM1) in MCF-7 cells suppresses anchorage-independent growth, whereas overexpression of miR-21 increases tumor growth. Zhu et al. [87] concluded that miR-21 acts as an oncogene by suppressing TPM1. Indeed, increased expression of TPM1 has been associated with decreased invasive and motile activities of melanoma cells [88, 89].

\section{MiR-21 enhances genetic instability of melanoma cells}

The DNA mismatch repair (MMR) protein MSH2 is an important tumor suppressor and crucial caretaker of the MMR, including transcription-coupled repair [90], homologous recombination [91], base excision repair [92], and plays an important role in mutation avoidance and microsatellite stability [93]. MSH2 is involved in the repair of UVA-induced oxidative DNA damage by base excision repair [94]. MSH2 gene mutations are present in the radial growth-phase of cutaneous malignant melanoma cell lines and can be further induced by UV-B [95]. Reduced or defective expression of MSH2 has been associated with high genomic instability, poor melanoma prognosis, and metastasis $[95,96]$. Reduced expression or function of MSH2 is either a result of mutation-derived dysfunction of $\mathrm{MSH} 2$ [94-97] or miR-21-mediated downregulation of MSH2 mRNA [98] (Figure 1).

Telomerase is reactivated in most cancers and there is accumulating evidence that this is a driver event in malignant melanoma [99-102]. hTERT is the catalytic subunit 
of telomerase, which regulates telomerase activity. Wang et al. [103] demonstrated in glioblastoma cells that enforced miR-21 expression increases hTERT expression mediated by STAT3, thereby promoting glioblastoma cell growth, whereas reduction of miR-21 represses hTERT expression in a STAT3-dependent fashion.

\section{Genetic and epigenetic changes in melanoma that upregulate miR-21}

The development and progression of melanoma can be attributed to independent or combined genetic and epigenetic events [104]. The MIR21 promoter region includes binding sites for activating protein 1 (AP-1) and signal transducer and activator of transcription 3 (STAT3) [19]. The AP-1 transcription factor c-Jun is highly expressed in melanoma cells [105]. AP-1/c-Jun activation results in enhanced expression of miR-21 [106-109]. Primary human melanocytes genetically modified to ectopically express BRAF(V600E) or NRAS (G12D) induce c-Jun expression [108-110] (Figure 2). RAS oncogenes are well-characterized inducers of AP-1 activity [109]. Indeed, oncogenic RAS induction in thyroid cells increases the expression of miR-21 [111]. Furthermore, an autoregulatory loop mediated by miR-21 and PDCD4 controls the AP-1 activity in RAS transformation [112].

Melanoma cells exhibit reduced expression of miR$125 \mathrm{~b}$, which is a negative regulator of c-Jun [113]. Thus, miR-125b/c-Jun/miR-21 signaling may represent a further pathway linked to miR-21-dependent melanomagenesis.

STAT3 is constitutively activated in a majority of human melanoma cell lines and tumor specimens [114, 115]. STAT3 activity is required for melanomagenesis and increases tumor invasiveness [116]. Noteworthy, STAT3 stimulates the expression of miR-21 [30, 40, 117]. In fact, STAT3/miR-21-signaling promotes proliferation and metastasis of B16 melanoma cells [42]. Inhibition of STAT3 is regarded as a potential therapeutic approach to target melanoma [118].

Approximately $50 \%$ of melanomas depend on mutant BRAF for proliferation, metastasis and survival [119]. Activation of STAT3 serine-727 and tyrosine-705 phosphorylations is promoted by BRAF(V600E) activity [118], whereas MEK inhibition decreases STAT3 phosphorylation in NRAS-mutant melanoma [119]. Furthermore, increased STAT3 signaling has been reported in primary oncogenic driver mutations of KIT, ALK, ROS1, RET and NTRK1 [12]. In addition, RAS-induced expression of miR-21 is mediated through STAT3 signaling [20]. Taken together, common driver mutations of malignant melanoma via AP-1 and STAT3 activate miR-21 signal transduction.
MiR-182 is upregulated in melanoma cell lines [8, 120]. Aberrant miR-182 expression promotes melanoma metastasis by repressing FOXO3 and microphthalmiaassociated transcription factor (MITF) [120]. It has recently been demonstrated that miR-182 is upregulated in melanoma cell lines after epigenetic modulation with the demethylating agents 5-aza-2'-deoxycytidine and trichostatin A [121]. It is concerning that miR-182 downregulates the expression of FOXO3 [121], which is a critical repressor of MIR21 [57]. Thus, enhanced miR-182 signaling due to oncogenic mutations or epigenetic upregulation may synergistically augment miR-21 expression in melanoma. The intertwined connection between epigenetics and miRs such as miR-182 modulate the activity of the epigenetic machinery that plays a role in cancer development $[122,123]$.

Dermal fibroplasia appears to be related to the degree of atypia in dysplastic nevi [124]. Periadnexal fibrosis has been observed in melanoma in situ [125]. Thus, subepidermal fibroplasia may be a co-feature of melanomagenesis. Recent evidence links skin fibrosis to miR signaling [126]. MiR-21 promotes fibrogenic EMT of epicardial mesothelial cells involving PDCD4 and Sprouty-1 [127]. MiR-21 has been identified as central regulator of fibrosis [128].

Cancer-associated fibrosis plays an important role for the tumor stroma that supports cancer growth and invasion. Inhibition of miR-21 reduces liver fibrosis and prevents the development of hepatocellular carcinoma [129]. A paracrine signaling network involving PDGF-CC and PDGF receptor- $\alpha$ in a mouse model of malignant melanoma accelerates tumor growth through recruitment and activation of different subsets of cancer-associated fibroblasts (CAFs) [130]. TGF- $\beta 1$ is a pivotal signal that promotes the generation of CAFs. Li et al. [131] demonstrated that miR-21 targets SMAD7, the upstream inhibitor of TGF- $\beta 1$ signaling. MiR-21 binds to the $3^{\prime}$ UTR of SMAD7 mRNA and inhibits its translation [131]. Overexpression of miR-21 or the depletion of SMAD7 promoted CAF formation [131]. These observations point to an important contribution of miR-21 in shaping melanoma's stromal microenvironment. Increased perilesional fibrosis may thus reflect the histologic result of enhanced miR-21 expression during the transition from a benign melanocytic lesion to malignant melanoma [14].

\section{Radiation-induced upregulation of $\mathrm{miR}-21$ Ultraviolet irradiation}

Ultraviolet radiation (UV) is regarded as a major risk factor for melanoma development [132, 133]. Both, UV-B and UV-A are implicated in melanomagenesis [134]. UV-B irradiation of human HaCaT keratinocytes and a human squamous carcinoma cell line releases IL-6 [135, 
136], which activates STAT3 signaling [137], and may consecutively increase the expression of miR-21 [30, 42]. Recent evidence underlines the predominant role of UV-A in melanomagenesis [138, 139]. Increased melanoma risk of airplane pilots has been linked to excessive UV-A exposure in the cockpit during flight time [140, 141]. In fact, miRs play an important role in photocarcinogenesis [142].

There is compelling evidence that miR-21 is upregulated by UV-A radiation of human skin [15]. Syed et al. [143] reported that both UV-A and UV-B irradiation of normal human epidermal keratinocytes activate STAT3. UV-B irradiation of the mouse epidermal JB6 cells induces the expression of miR-21 [144]. Radiationinduced bystander effects are established photobiological phenomena. Xu et al. [145] report significant upregulation of miR-21 in both directly irradiated cells and bystander cells. Notably, irradiated cells export miRs via exosomes [145-147] (Figure 3). Exosomes mediate cellcell communication in a variety of biological processes and are considered as a new class of most important signalosomes that transport regulatory miRs between cells $[148,149]$. Not only ionizing radiation but also UVirradiation induces bystander effects in keratinocytes, fibroblasts and melanoma cells [150-153]. UV-induced expression of miR-21 in bystander keratinocytes may thus enhance exosomal miR-21 signaling, which affects gene regulation of adjacent melanocytic cells (Figure 3).

\section{Radiofrequency fields}

There is a strong correlation between the accessibility to air travel and increasing melanoma incidence [154]. However, UV-irradiation may not represent the only electromagnetic spectrum associated with increased melanoma risk. A good correlation in time has been found for the rollout of FM/TV broadcasting networks and increasing melanoma prevalence [155]. Notably, enhanced STAT3 activation in response to $1,800 \mathrm{MHz}$ radiofrequency fields has recently been demonstrated in astrocytes and microglia [156]. Compared to the general population, the incidence rate of gliomas is greater among melanoma patients [157]. In this regard, it is considerable that both glia cells and melanocytes derive from common neural crest cells [158]. Mutant gene expression of p53 in the peripheral zone of glioblastoma has been increased by $65 \%$ in patients using cell phones more than $3 \mathrm{~h}$ per day [159]. As in melanomas [13, 14], miR21 is significantly overexpressed in glioblastomas [160].

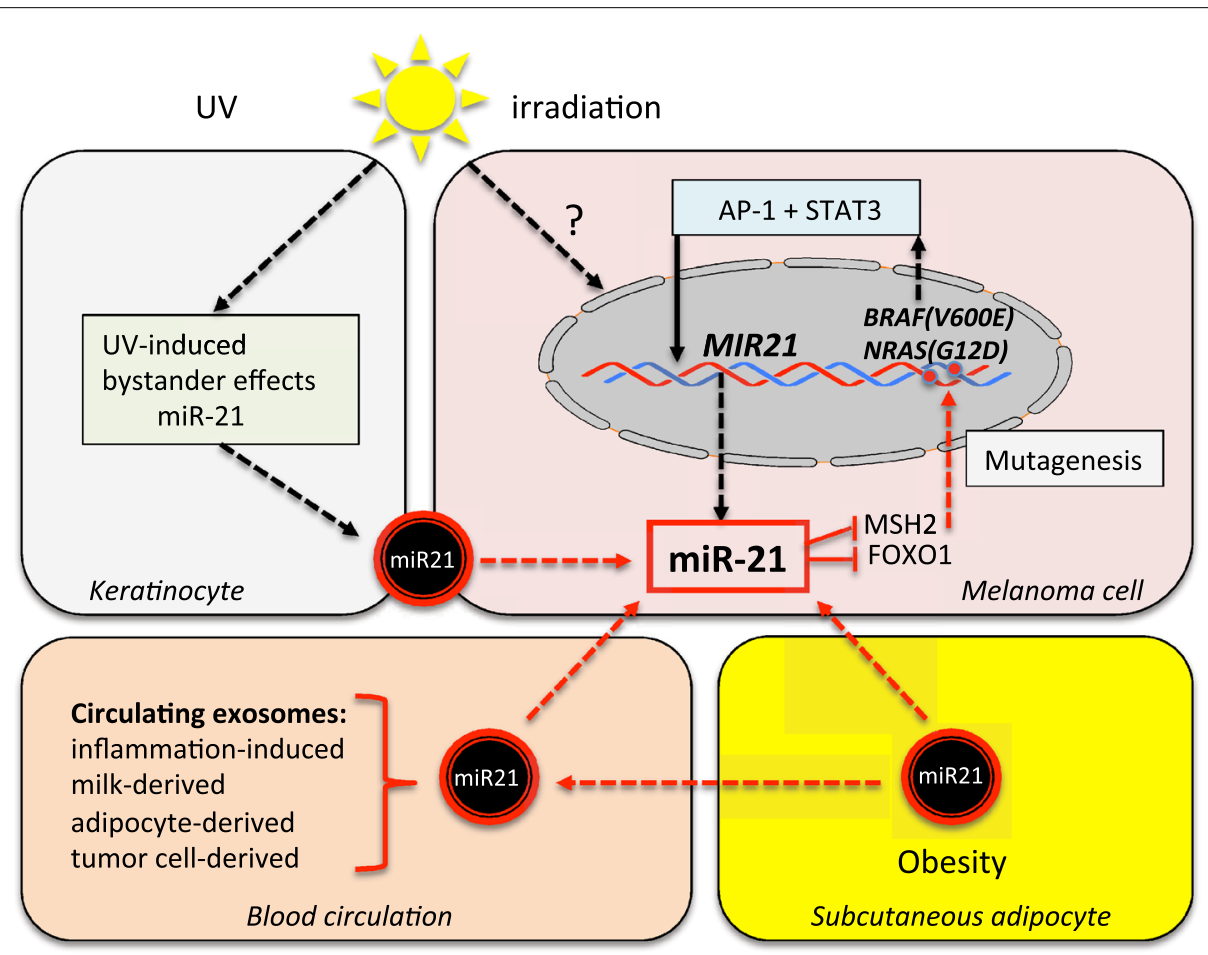

Figure 3 Working model of exogenous and endogeneous factors that increase exosomal miR-21 signaling in malignant melanoma. The common BRAF(V600E) and NRAS(G12D) mutations in cutaneous melanoma increase miR-21 expression by upregulating AP-1 and STAT3. Keratinocytederived exosomal miR-21 induced by UV-irradiation, exosomal miR-21 derived from the systemic circulation induced by dietary and environmental factors as well as obesity- and inflammation-associated exosomal miR-21 may enhance the total burden of miR-21 signaling of melanocytes promoting the transition to the malignant phenotype. 
The International Agency for Research on Cancer of the WHO classified radiofrequency electromagnetic fields as possibly carcinogenic to humans [161]. Thus, not only UV but also other electromagnetic spectra may activate oncogenic STAT3/miR-21 signaling.

\section{Upregulation miR-21 via circulating exosomes Milk exosome-derived miR-uptake}

Bovine milk provides abundant bioactive exosomal miRs [162-164]. Exosomal miRs of pasteurized cow's milk, such as miR-29b, are absorbed by humans in biologically meaningful amounts, which reaches the systemic circulation and affects gene expression of the milk consumer $[16,17]$. It has been estimated that the $245 \mathrm{miRs}$ detected in cow's milk affect more than 11,000 human genes [16]. Milk has been proposed to represent an epigenetic transfection system that maintains maternal miR signaling to the newborn infant to promote postnatal growth [17]. Remarkably, bovine miRs of cow's milk survive milk processing such as pasteurization, homogenization and refrigerated storage for over 2 weeks [165]. Due to lactase persistence, Caucasian populations are able to consume pasteurized fresh milk, which has been introduced into the food chain for daily consumption through the availability of widespread cooling technology since the mid1950's: The decade during which melanoma incidence increased substantially.

Exosomes facilitate miR transport over long distances [166]. Milk is obviously a mammalian interindividual miR-transfer system intended to provide maternal generegulatory signals to the newborn [17]. Intriguingly, bovine miR-21, a predominant miR constituent of cow's milk [164, 167, 168], is identical to human miR-21 (http:// www.mirbase.org). Notably, milk exosomes have been proven to be resistant against harsh degrading conditions $[167,168]$.

Recent epidemiological evidence links increased milk consumption to the pathogenesis of hepatocellular carcinoma [169]. In HepG2 hepatocellular carcinoma cells, interleukin 6 (IL-6) induces STAT3-dependent miR-21 transcription [170]. Michaëlsson et al. [171] reported a positive correlation between milk intake and overall mortality and increased IL-6 serum levels in two Swedish cohorts. Notably, increased serum IL-6 levels have been correlated with a worse prognosis of melanoma [172, 173]. Milk also delivers exosomal miR-155 [164], which is involved in STAT3-mediated tumorigenesis [174, 175]. MiR-155 enhances STAT3 expression by reducing suppressor of cytokine signaling 1 (SOCS1), a target of miR155 [175, 176]. Grignol et al. [16] observed increased expression of both miR-21 and miR-155 during the progression of melanocytic lesions. Pieters et al. showed that commercial milk exosomes transmit TGF- $\beta$ [168]. TGF $\beta$ signaling promotes a rapid increase in the expression of mature miR-21 through promoting the processing of primary transcripts of miR-21 (pri-miR-21) into precursor miR-21 (pre-miR-21) by the DROSHA complex [177]. Thus, intake of pasteurized milk may increase miR-21 signaling either through direct exosomal transfer of miR21 or via STAT3- and TGF $\beta$-mediated upregulation of miR-21 expression.

\section{Tumor exosome-derived miR-21}

Not only milk provides miR-21 via exosome transfer but also tumor cells. Intriguingly, miR content of circulating tumor-derived exosomes has been found to correlate with the miR profile of the tumor [178, 179]. In patients with ovarian cancer, lung cancer and glioblastoma, miR-21 is one of the most abundant miRs detected in the patients' circulating exosomes $[178,179]$. The uptake of miR-21 delivering exosomes is facilitated via clathrin-mediated endocytosis and macropinocytosis [180]. Notably, it has been demonstrated that tumor cell-derived exosomes regulate target gene expression in normal cells [180]. MiR-21 is also one of the major exosomal miRs released from melanoma cells [44, 181, 182]. Indeed, plasma miR-21 levels have been associated with the tumor burden in cutaneous melanoma [44]. Thus, exosomal melanoma-derived miR-21 may promote melanoma invasion and distant metastasis. According to a recent concept, tumor-derived exosomal miRs such miR21 may be involved in tumor-mediated immunosuppression [183]. For instance, nasopharyngeal cancer-derived miR-21 induces IL-10 and B-cells that suppress CD8+ T-cell activities [184]. Moreover, miR-21 is involved in the generation of myeloid-derived suppressor cells (MDSCs), which exert potent immunosuppressive activities [185]. Recent evidence underlines that high levels of MDSCs are associated with a poor overall survival of melanoma patients [186]. Furthermore, miR-21 targets two important regulatory checkpoints in the TLR signaling pathway, myeloid differentiation factor 88 (MyD88) and interleukin-1 receptor-associated kinase 1 (IRAK1) [187]. Moreover, tumor-secreted miR-21 can function via binding as ligands to murine TLR7 and human TLR8 in immune cells, thereby triggering a TLR-mediated prometastatic inflammatory response that ultimately may lead to tumor growth and metastasis [188].

\section{Age- and inflammation-induced miR-21}

MiR-21 is a major miR component of human plasma that increases in association with age, inflammation, cardiovascular disease, and obesity [189-191]. STAT3 activation of miR-21 has been proposed as a mechanistic link between inflammation and cancer development [192]. Inflammasome activation and increased IL- $1 \beta$ signaling 
has recently been proposed to play a potential role in driving melanomagenesis [193]. Serum IL-1 $\beta$ is significantly increased in advanced melanoma patients [194]. Remarkably, it has been demonstrated in human aortic epithelial cells that IL-1 $\beta$ treatment induces a three to fourfold response of miR-21-3p expression compared with control treatment [195]. This can be explained by IL-1 $\beta$-induced IL-6/STAT3 signaling [196].

Inflammation is a newly recognised hallmark of cancer that substantially contributes to the development and progression of malignancies [197]. Increasing evidence underlines the role that local immune response and systemic inflammation have in the progression of tumors and survival of cancer patients. It has recently been proposed that miR-21 plays a key role in the induction and resolution of inflammatory responses [198] and in the regulation of immune homeostasis [196]. Tumor necrosis factor- $\alpha$-induced protein 8 -like 2 (TIPE2), which belongs to the TNF- $\alpha$-induced protein- 8 family, is a negative regulator of innate and adaptive immunity and is a direct target of miR-21 [199, 200]. TIPE2 negatively regulates inflammation by switching arginine metabolism from nitric oxide synthase to arginase, which converts arginine to ornithine and urea [201]. Melanomas are auxotrophic for arginine due to the reduced expression of argininosuccinate synthetase-1 (ASS1), which is the rate-limiting enzyme for arginine biosynthesis [202]. Furthermore, miR-21-regulated TIPE2 controls innate immunity to RNA by targeting the PI3K-RAC pathway [203]. TIPE2 is able to suppress TNF- $\alpha$-induced hepatocellular carcinoma metastasis by inhibiting ERK1/2 and NF- $\kappa B$ activation [204]. Downregulated TIPE2 is associated with increased cell proliferation and poor prognosis in non-small lung cancer [205]. Furthermore, TIPE2 provides a molecular bridge from inflammation to cancer by targeting the RAS signaling pathway [206, 207]. TIPE2 binds the RAS-interacting domain of the RALGDS (RAL guanine nucleotide dissociation stimulator) family of proteins, which are essential effectors of activated RAS. This binding prevents RAS from forming an active complex, thereby inhibiting the activation of the downstream signaling molecules RAL and AKT [207]. Thus, miR-21 reduces TIPE2-mediated suppression of RAS-induced tumorigenesis, which may have a potential impact on RAS-driven melanomagenesis.

\section{Association of nutrition and lifestyle factors overexpressing miR-21 \\ High glucose consumption}

Western diet is characterized by excessive consumption of sugar and hyperglycemic carbohydrates resulting in excessive glucose intake. About $75 \%$ of all foods and beverages contain added sugar in a large array of forms. Consumption of soft drinks has increased fivefold since 1950 [208]. It has recently been demonstrated that miR-21 is upregulated in a time-dependent manner in response to high concentration glucose stimulation in Raw 264.7 macrophages [209]. Inhibition of miR-21 increases mRNA and protein levels of PDCD4 [209]. Thus, the steady increase in daily glucose consumption may be related to the total burden of miR-21.

\section{High fat intake and obesity}

Several studies demonstrated an association between increased BMI and melanoma incidence and mortality [3]. MiR-21 is involved in adipocyte differentiation and is upregulated in subcutaneous adipose tissue of obese individuals [210, 211]. A long-term high-fat diet (HFD) upregulates murine miR-21 and induces obesity in mice [212]. MiR-21 is robustly expressed in human adipose tissue and positively correlates with BMI [211], whereas long-term inhibition of miR-21 reduces obesity in $\mathrm{db} /$ $\mathrm{db}$ mice [213]. Pandey et al. [214] provided evidence that HFD-induced obesity leads to increased melanoma progression in male C57BL/6J mice associated with enhanced Cav-1 and FASN expression in tumors from HFD mice. Cav-1 and FASN are coordinately regulated and Cav-1 interacts with FASN in melanoma cells [214]. In accordance with this, Malvi et al. [215] demonstrated that reduction of caloric intake by orlistat treatment of obese mice significantly diminishes melanoma progression. Interestingly enough, adipocytes secrete exosomes containing abundant miRs [216, 217]. In the B16F10 melanoma allograft model, adipose tissue conditioned media from HFD-induced obese mice increase lymphangiogenesis and lymph node metastasis [218]. Exposure to media from adipocyte cultures increases cell proliferation and reduces sensitivity of melanoma cells to apoptosis induced by cisplatin and docetaxel [219]. Notably, miR-21 has been shown to decrease chemosensitivity of cancer cells to cisplatin [220,221] and docetaxel [222, 223]. Future studies should elucidate whether adipocytederived miR-21 may play a role in melanomagenesis (Figure 3).

\section{Alcohol consumption}

There is epidemiological evidence that drinking alcohol is associated with an increased risk of melanoma [224, 225]. Expression of miR-21 and several of their target genes are regulated by acute psychological stress and have been correlated with alcohol consumption in a laboratory setting [226].

\section{Sedentary lifestyle}

Sedentary lifestyle with insufficient physical activity is not only a risk factor for obesity but may be related to 
the increasing prevalence of melanoma in industrialized societies. In fact, US men and women exercising five to seven days per week have been reported to be at decreased risk of melanoma [227]. In accordance with this, a melanoma-protective effect of increased physical exercise has been reported in Greece [228]. Nielsen et al. [229] observed a decrease of circulating plasma miR-21 in response to chronic exercise. Thus, a sedentary lifestyle may adversely affect miR-21 signaling.

\section{Pollution-mediated upregulation of miR-21}

Smoking and nicotine exposure upregulates the expression of miR-21 [67, 230]. Chronic arsenic exposure acts as a co-carcinogen in melanoma [231]. Arsenic exposure induces the expression of miR-21 [65, 232-235]. A recent study shows that miR-21 is involved in exosomemediated intercellular communication between neoplastic and normal human bronchial epithelial (HBE) cells [236]. Exosomes derived from arsenite-transformed HBE cells stimulate proliferation of normal HBE cells, whereas exosomes from miR-21-depleted cells fail to stimulate proliferation. Collectively, these data support the concept that exosomal miR-21 is involved in cell-cell communication during carcinogenesis induced by environmental chemicals. Furthermore, air pollution and oxidative stress induce the expression of miR-21. It has been demonstrated that metal-rich particulate matter increases the expression of miR-21 in peripheral blood leukocytes [237]. Notably, miR-21 expression has been associated with exposure to diesel exhaust linked to increased plasma levels of 8-hydroxy-deoxyguanosine (8-OHdG) [238]. 8-OHdG is induced in DNA by oxidative stress and UV irradiation [239]. Indeed, melanoma patients with low expression of nuclear 8-OHdG have significantly longer survival times compared to those with high expression [240]. Thus, air pollution and urbanisation may affect melanomagenesis via environmental stressors that upregulate miR-21 expression (Table 1 ).

\section{Conclusions}

Overexpression miR-21 is a common molecular feature of malignant melanoma [13]. MiR-21 plays a crucial role in regulatory circuits involving epigenetic switches required for the transformation of cancer cells [192]. MiR-21 expression is upregulated by environmental, epigenetic and genetic changes that may all promote melanomagenesis. In comparison to epidermal keratinocytes, environment insults are apparently more critical for melanocytes, as these cells are considerably more resistant to apoptosis [241-243]. Thus, environmental and epigenetic factors that persistently increase miR-21 signaling may have predominantly long-lasting impacts on melanocytes. In this regard, melanoma appears to represent a
Table 1 Environmental and lifestyle factors suggested to upregulate miR-21 signaling

\begin{tabular}{|c|c|}
\hline MiR-21 stimulus & Mode of action [Refs.] \\
\hline UV-irradiation & IL-6, STAT3; exosome release $[15,135-137]$ \\
\hline Cell phone use & STAT3 upregulation [156] \\
\hline Smoking & Increased miR-21 expression $[67,230]$ \\
\hline Alcohol abuse & Increased miR-21 expression [226] \\
\hline \multirow[t]{2}{*}{ Pollution } & $\begin{array}{l}\text { Increased miR-21 expression by particulate matter } \\
\text { [237] }\end{array}$ \\
\hline & Increased miR-21 expression by diesel exhaust [238] \\
\hline \multirow[t]{2}{*}{ Arsenic } & Increased miR-21 expression [65, 232-235] \\
\hline & Exosome release of bronchial epithelial cells [236] \\
\hline Inflammation & IL-1 $\beta$, IL-6, STAT3 [192-198] \\
\hline \multirow[t]{2}{*}{ Milk consumption } & $\begin{array}{l}\text { Uptake of milk-delivered exosomal miR-21 [16, 17, } \\
\text { 162-168] }\end{array}$ \\
\hline & Transfer of bovine miR-155, STAT3; IL-6 [169, 170, 173] \\
\hline \multirow[t]{2}{*}{ Obesity } & Increased adipocyte miR-21 expression $[210,212]$ \\
\hline & Adipocyte-derived exosome release [211-216] \\
\hline Tumor diseases & $\begin{array}{l}\text { Release of tumor cell-derived exosomes [44, } \\
\text { 178-186] }\end{array}$ \\
\hline Sedentary lifestyle & Physical exercise decreases miR-21 expression [229] \\
\hline Higher age & Increased plasma miR-21 levels [189] \\
\hline
\end{tabular}

prototype of a cancer that is promoted by environmental factors.

Apparently, the expression of miR-21 steadily increases during the transition of a benign melanocytic to a borderline and malignant lesion [14]. MiR-21 is an oncomiR that intersects with all hallmarks of cancer: (1) sustaining proliferative signaling, (2) evading growth suppressors, (3) activating invasion and metastasis, (4) enabling replicative immortality, (5) inducing angiogenesis, (6) resisting cell death, and (7) inflammation [197, 244] (Figure 1). Exosome-derived miRs have been implicated to play a major role in the development and progression of cancer by epigenetic reprogramming [245]. Westernized environments, nutrition, and lifestyle may modify epigenetic programming via miR-21.

The most common BRAF and RAS mutations of melanoma are associated with increased miR-21 expression (Figure 2). Upregulated miR-21 expression induced by various lifestyle factors and environmental conditions of industrialized countries may be the converging point of oncogenic stimuli promoting melanomagenesis. Increased expression of miR-21 has been observed in association with UV-irradiation and other electromagnetic radiation, smoking, pollution with exposure to particulate matter and diesel exhaust. MiR-21 signaling of melanoma cells may be upregulated by exosomal transfer of miR-21.

Exosomes have been identified as major players maintaining a molecular crosstalk between tumor cells and 
cell of the innate immune system [246]. Exosomes may reach pigmented lesions either via bystander effects of UV-irradiated keratinocytes or via the circulation or underlying subcutaneous adipose tissue in obesity. Thus, environmental and intrinsic factors may work in an additive or synergistic manner, thereby increasing the total individual burden of miR-21 signaling (Figure 3). It is of special concern that miR-21 not only promotes melanoma progression, but that it is also involved in the initiation of melanoma. MiR-21-mediated suppression of MSH2-dependent DNA mismatch repair, insufficient FoxO-controlled ROS-homeostasis, imbalances of FBXO11-regulated proteasomal degradation of critical proteins involved in cell proliferation and apoptosis, and miR-21-stimulated telomerase activity may all increase genetic instability promoting the risk of mutagenesis. In this regard, miR-21 may represent the common denominator of accumulating environmental and intrinsic stressors that drive the initiation and progression of malignant melanoma (Figure 3).

The versatility of miRs as molecular tools inspires the design of novel strategies for the treatment of malignant melanoma [247]. As suggested for glioblastoma and ovarian carcinoma [248, 249], anti-miR-21 treatment may be a promising option for the treatment of malignant melanoma [79]. It has been demonstrated that the curcumin analog EF24 exhibited potent anticancer activity in B16 murine melanoma cells associated with a downregulation of miR-21 [250]. Furthermore, inhibition of miR-21 increases chemosensitivity in a variety of tumors [220-223]. There is further evidence that anti-miR-21 treatment downregulates the anti-apoptotic mitochondrial membrane protein BCL2 (B-cell leukemia 2), which blocks apoptotic cell death [251]. BCL2 is a MITF target gene involved in melanocyte and melanoma cell proliferation and survival [252, 253]. Combined inhibition of NF- $\mathrm{BB}$ and BCL2 triggers synergistic reduction of viability and induces apoptosis in melanoma cells [254]. Remarkably, miR-21 inhibition suppresses proliferation and migration of nasopharyngeal carcinoma and breast cancer cells through downregulation of anti-apoptotic BCL2 [255, 256]. Furthermore, disruption of miR-21 by transcription activator-like effector nucleases (TALENs) in cancerous cells lead to diminished cell transformation and increased expression of cell-environment interaction genes [257].

Taken together, melanoma is a model cancer system not only involving genetic but also environmental components [258]. At the molecular level, miR-21 links environmental exposure to melanomagenesis. Circulating exosomal miRs, especially miR-21, represents a very important signaling system of cell communication [259] that apparently mediates the impact of environmental and epigenetic factors in melanomagenesis. Circulating and locally generating exosomal miR-21 through various environmental stimuli may significantly contribute to the multistep process of melanomagenesis. Decreasing the input and magnitude of extrinsic and intrinsic stimuli that promote overexpression and release of exosomal miR-21 may thus be a very promising approach in the prevention and treatment of melanoma, the most serious human skin disease that is apparently promoted by common Western lifestyle factors.

\section{Abbreviations}

AP-1: activating protein 1; APAF1: apoptotic protease activating factor 1; BCL2: B-cell leukemia 2; BMI: body mass index; BRAF: V-RAF murine sarcoma viral oncogene homolog B1; BTG2: B-cell translocation gene 2; CAF: cancerassociated fibroblast; EMT: epithelial-mesenchymal transition; FAS: FAS cell surface death receptor; FASLG: FAS ligand; FBXO11: F-box only protein 11; FOXO1: forkhead box O1; HIF-1 $\alpha$ : hypoxia-inducible factor $1 \alpha$; hTERT: human telomerase reverse transcriptase; MiR: micro-ribonucleic acid; IGFBP3: insulin like growth factor binding protein 3; IRAK1: interleukin 1 receptor-associated kinase 1; L1CAM: L1 cell adhesion molecule; MDSC: myeloid-derived suppressor cell; MITF: microphthalmia-associated transcription factor; MMR: DNA mismatch repair; MSH2: MutS, E. coli, homolog of, 2; mTORC1: mechanistic target of rapamycin complex 1; MyD88: nyeloid differentiation primary response gene 88; NRAS: neuroblastoma RAS viral oncogene homolog; 8-OhdG: 8-hydroxydeoxyguanosine; PDCD4: programmed cell death protein; PI3K: phosphoinositol-3 kinase; PTEN: phosphatase and tensin homolog; RALGDS: RAL guanine nucleotide dissociation stimulator; ROS: reactive oxygen species; RTK: receptor tyrosine kinase; SOCS1: suppressor of cytokine signaling 1; STAT3: signal transducer and activator of transcription 3; TGFBR1: transforming growth factor beta receptor type 1; TIMP3: tissue inhibitor of metalloproteinase 3; TGF $\beta$ : transforming growth factor beta; TIPE2: tumor necrosis factoralpha-induced protein 8-like 2; TNF-R1: tumor necrosis factor receptor-1;TPM1: tropomyosin 1;TRAIL-R1: TNF-related apoptosis inducing ligand receptor-1; UV: ultraviolet radiation; VEGF: vascular endothelial growth factor.

\section{Acknowledgements}

There are no sources of funding. The author thanks Mrs. Helena Ord, student of Princeton University, for substantial language improvements of this manuscript.

\section{Compliance with ethical guidelines}

\section{Competing interests}

The author declares that he has no competing interests.

Received: 1 March 2015 Accepted: 10 June 2015

Published online: 27 June 2015

\footnotetext{
References

1. Erdei E, Torres SM (2010) A new understanding in the epidemiology of melanoma. Expert Rev Anticancer Ther 10:1811-1823

2. Jiang AJ, Rambhatla PV, Eide MJ (2014) A systematic review of socioeconomic and lifestyle factors and melanoma. $\mathrm{Br} J$ Dermatol 172:885-915

3. Candido S, Rapisarda V, Marconi A, Malaponte G, Bevelacqua V, Gangemi P et al (2014) Analysis of the B-RafV600E mutation in cutaneous melanoma patients with occupational sun exposure. Oncol Rep 31:1079-1082

4. Vrijens K, Bollati V, Nawrot TS (2015) MicroRNAs as potential signatures of environmental exposure or effect: a systematic review. Environ Health Perspect 123:399-411
} 
5. Yi R, Poy MN, Stoffel M, Fuchs E (2008) A skin microRNA promotes differentiation by repressing 'stemness'. Nature 452:225-229

6. Di Leva G, Garofalo M, Croce CM (2014) microRNAs in cancer. Ann Rev Pathol. 9:287-314

7. Sand M, Skrygan M, Sand D, Georgas D, Gambichler T, Hahn SA et al (2013) Comparative microarray analysis of microRNA expression profiles in primary cutaneous malignant melanoma, cutaneous malignant melanoma metastases, and benign melanocytic nevi. Cell Tissue Res 351:85-98

8. Kunz M (2013) MicroRNAs in melanoma biology. Adv Exp Med Biol 774:103-120

9. Tembe V, Schramm SJ, Stark MS, Patrick E, Jayaswal V, Tang YH et al (2015) MicroRNA and mRNA expression profiling in metastatic melanoma reveal associations with BRAF mutation and patient prognosis. Pigment Cell Melanoma Res 28:254-266

10. Bandarchi B, Jabbari CA, Vedadi A, Navab R (2013) Molecular biology of normal melanocytes and melanoma cells. J Clin Pathol 66:644-648

11. Bogenrieder T, Herlyn M (2011) The molecular pathology of cutaneous melanoma. Cancer Biomarkers 9:267-286

12. Bastian BC (2014) The molecular pathology of melanoma: an integrated taxonomy of melanocytic neoplasia. Annu Rev Pathol Mech Dis. 9:239-271

13. Satzger I, Mattern A, Kuettler U, Weinspach D, Niebuhr M, Kapp A et al (2012) microRNA-21 is upregulated in malignant melanoma and influences apoptosis of melanocytic cells. Exp Dermatol 21:509-514

14. Grignol V, Fairchild ET, Zimmerer JM, Lesinski GB, Walker MJ, Magro CM et al (2011) miR-21 and miR-155 are associated with mitotic activity and lesion depth of borderline melanocytic lesions. Br J Cancer 105:1023-1029

15. Syed D, Khan MI, Shabbir M, Mukhtar H (2013) MicroRNAs in skin response to UV radiation. Curr Drug Targets 14:1128-1134

16. Baier SR, Nguyen C, Xie F, Wood JR, Zempleni J (2014) MicroRNAs are absorbed in biologically meaningful amounts from nutritionally relevant doses of cow milk and affect gene expression in peripheral blood mononuclear cells, HEK- 293 kidney cell cultures, and mouse livers. J Nutr 144:1495-1500

17. Melnik BC, John SM, Schmitz G (2013) Milk is not just food but most likely a genetic transfection system activating mTORC1 signaling for postnatal growth. Nutr J 12:103

18. Medina PP, Nolde M, Slack FJ (2010) OncomiR addiction in an in vivo model of microRNA-21-induced pre-B-cell lymphoma. Nature 467:86-90

19. Krichevsky AM, Gabriely G (2009) miR-21: a small multi-faceted RNA. J Cell Mol Med 13:39-53

20. Becker Buscaglia LE, Li Y (2011) Apoptosis and the target genes of miR21. Chin. J Cancer. 30:371-380

21. Meng F, Henson R, Wehbe-Janek H, Ghoshal K, Jacob ST, Patel T (2007) MicroRNA-21 regulates expression of the PTEN tumor suppressor gene in human hepatocellular cancer. Gastroenterology 133:647-658

22. Han M, Liu M, Wang Y, Chen X, Xu J, Sun $Y$ et al (2012) Antagonism of miR-21 reverses epithelial-mesenchymal transition and cancer stem cell phenotype through AKT/ERK1/2 incactivation by targeting PTEN. PLoS One 7:e39520

23. Sayed D, Rane S, Lypowy J, He M, Chen IY, Vashistha H et al (2008) MicroRNA-21 targets Sprouty2 and promotes cellular outgrouths. Mol Biol Cell 19:3272-3282

24. Dariminpourain M, Wang S, Ittmann M, Kwabi-Addo B (2011) Transcriptional and post-transcriptional regulation of Sprouty1, a receptor tyrosine kinase inhibitor in prostate cancer. Prostate Cancer Prostatic Dis 14:279-285

25. Frey MR, Carraro G, Batra RK, Polk DB, Warburton D (2011) Sprouty keeps bowel kinases regular in colon cancer, while miR-21 targets Sprouty. Cancer Biol Ther 11:122-124

26. Asangani IA, Rasheed SA, Nikolova DA, Leupold JH, Colburn NH, Post S et al (2008) MicroRNA-21 (miR-21) post-transcriptionally downregulates tumor suppressor $\mathrm{Pdcd} 4$ and stimulates invasion, intravasation and metastasis in colorectal cancer. Oncogene 27:2128-2136

27. Lu Z, Liu M, Stribinskis V, Klinge CM, Ramos KS, Colburn NH et al (2008) MicroRNA-21 promotes cell transformation by targeting the programmed cell death 4 gene. Oncogene 27:4373-4379
28. Carayol N, Katsoulidis E, Sassano A, Altman JK, Druker BJ, Platanias LC (2008) Suppression of programmed cell death 4 (PDCD4) protein expression by BCR-ABL-regulated engagement of the mTOR/p70 S6 kinase pathway. J Biol Chem 283:8601-8610

29. Peacock O, Lee AC, Cameron F, Tarbox R, Vafadar-Isfahani N, Tufarelli $C$ et al (2014) Inflammation and MiR-21 pathways functionally interact to downregulate PDCD4 in colorectal cancer. PLoS One 9:e110267

30. Papagiannakopoulos T, Shapiro A, Kosik KS (2008) MicroRNA-21 targets a network of key tumor-suppressive pathways in glioblastoma cells. Cancer Res 68:8164-8172

31. Ng R, Song G, Roll GR, Frandsen NM, Willenbring H (2012) A microRNA-21 surge facilitates rapid cyclin D1 translation and cell cycle progression in mouse liver regeneration. J Clin Invest 122:1097-1108

32. Liu LZ, Li C, Chen Q, Jing Y, Carpenter R, Jiang $Y$ et al (2011) MiR-21 induced angiogenesis through AKT and ERK activation and HIF-1 $\alpha$ expression. PLoS One 6:e19139

33. Zhao D, Tu Y, Wan $L, B u L$, Huang T, Sun $X$ et al (2013) In vivo monitoring of angiogenesis inhibition via down-regulation of mir-21 in a VEGFR2luc murine breast cancer model using bioluminescent imaging. PLoS One 8:e71472

34. Zhao $Y, X u$ Y, Luo F, Xu W, Wang B, Pang $Y$ et al (2013) Angiogenesis, mediated by miR-21, is involved arsenite-induced carcinogenesis. Toxicol Lett 223:35-41

35. Giatromanolaki A, Sivridis E, Kouskoukis C, Gatter KC, Harris AL, Koukourakis MI (2003) Hypoxia-inducible factors 1alpha and 2alpha are related to vascular endothelial growth factor expression and a poorer prognosis in nodular malignant melanomas of the skin. Melanoma Res 13:493-495

36. Hanna SC, Krishnan B, Bailey ST, Moschos SJ, Kuan PF, Shimamura T et al (2013) HIF1 $\alpha$ and HIF2 $\alpha$ independently activate SRC to promote melanoma metastases. J Clin Invest 123:2078-2093

37. Watanabe T, Hirota Y, Arakawa Y, Fujisawa H, Tachibana O, Hasegawa M et al (2003) Frequent LOH at chromosome 12q22-23 and Apaf-1 inactivation in glioblastoma. Brain Pathol 13:431-439

38. Soengas MS, Capodieci P, Polsky D, Mora J, Esteller M, Opitz-Araya X et al (2001) Inactivation of the apoptosis effector Apaf-1 in malignant melanoma. Nature 409:207-211

39. Campioni M, Santini D, Tonini G, Murace R, Dragonetti E, Spugnini EP et al (2005) Role of Apaf-1, a key regulator of apoptosis, in melanoma progression and chemoresistance. Exp Dermatol 14:811-818

40. Mustika R, Budiyanto A, Nishigori C, Ichihashi M, Ueda M (2005) Decreased expression of Apaf-1 with progression of melanoma. Pigment Cell Res 18:59-62

41. Niedojadło K, Łabedzka K, Łada E, Milewska A, Chwirot BW (2006) Apaf-1 expression in human cutaneous melanoma progression and in pigmented nevi. Pigment Cell Res 19:43-50

42. Yang CH, Yue J, Pfeffer SR, Handorf CR, Pfeffer LM (2011) MicroRNA-21 regulates the metastatic behavior of B16 melanoma cells. J Biol Chem 286:39172-39178

43. Jiang L, Lv X, Li J, Li J, Li X, Li W et al (2012) The status of microRNA21 expression and its clinical significance in human cutaneous malignant melanoma. Acta Histochem 114:582-588

44. Saldanha G, Potter L, Shendge P, Osborne J, Nicholson S, Yii N et al (2013) Plasma microRNA-21 is associated with tumor burden in cutaneous melanoma. J Invest Dermatol 133:1381-1384

45. Huang Y, Yang YB, Zhang XH, Yu XL, Wang ZB, Cheng XC (2013) MicroRNA-21 gene and cancer. Med Oncol 30:376

46. Edwin F, Anderson K, Ying C, Patel TB (2009) Intermolecular interactions of Sprouty proteins and their implications in development and disease. Mol Pharmacol 76:679-691

47. Xiong B, Cheng Y, Ma L, Zhang C (2013) MiR-21 regulates biological behavior through the PTEN/PI-3K/Akt signaling pathway in human colorectal cancer cells. Int J Oncol 42:219-228

48. Xu M, Mo YY (2012) The Akt-associated microRNAs. Cell Mol Life Sci 69:3601-3612

49. Yang CH, Yue J, Fan M, Pfeffer LM (2010) IFN induces miR-21 through a signal transducer and activator of transcription 3-dependent pathway as a suppressive negative feedback on IFN-induced apoptosis. Cancer Res 70:8108-8116 
50. Schlegel NC, von Planta A, Widmer DS, Dummer R, Christofori G (2015) PI3K signalling is required for a TGF $\beta$-induced epithelial-mesenchymal-like transition (EMT-like) in human melanoma cells. Exp Dermatol 24:22-28

51. Conde-Perez A, Larue L (2012) PTEN and melanomagenesis. Future Oncol 8:1109-1120

52. Dansen TB, Burgering BM (2008) Unravelling the tumor-suppressive functions of FOXO proteins. Trends Cell Biol 18:421-429

53. Lei BX, Liu ZH, Li ZJ, Li C, Deng YF (2014) miR-21 induces cell proliferation and suppresses the chemosensitivity in glioblastoma cells via downregulation of FOXO1. Int J Clin Exp Med. 7:2060-2066

54. Song W, Wang L, Wang L, Li Q (2015) Interplay of miR-21 and FoxO1 modulates growth of pancreatic ductal adenocarcinoma. Tumour Biol [Epub ahead of print]

55. Zanella F, Renner O, García B, Callejas S, Dopazo A, Peregrina S et al (2010) Human TRIB2 is a repressor of FOXO that contributes to the malignant phenotype of melanoma cells. Oncogene 29:2973-2982

56. Kim J, Choi H, Cho EG, Lee TR (2014) FoxO3a is an antimelanogenic factor that mediates antioxidant-induced depigmentation. J Invest Dermatol 134:1378-1388

57. Wang K, Li PF (2010) Foxo3a regulates apoptosis by negatively targeting miR-21. J Biol Chem 285:16958-16966

58. Essaghir A, Dif N, Marbehant CY, Coffer PJ, Demoulin JB (2009) The transcription of FOXO genes is stimulated by $\mathrm{FOXO} 3$ and repressed by growth factors. J Biol Chem 284:10334-10342

59. Tzivion G, Dobson M, Ramakrishnan G (2011) FoxO transcription factors; Regulation by AKT and 14-3-3 proteins. Biochim Biophys Acta 1813:1938-1945

60. Wang Y, Zhou Y, Graves DT (2014) FOXO transcription factors: their clinical significance and regulation. Biomed Res Int 2014:925350

61. Lankat-Buttgereit B, Göke R (2009) The tumour suppressor Pdcd4: recent advances in the elucidation of function and regulation. Biol Cell 101:309-317

62. Dennis MD, Jefferson LS, Kimball SR (2012) Role of p70S6K1-mediated phosphorylation of elF4B and PDCD4 proteins in the regulation of protein synthesis. J Biol Chem 287:42890-42899

63. Vikhreva PN, Korobko IV (2014) Expression of Pdcd4 tumor suppressor in human melanoma cells. Anticancer Res 34:2315-2318

64. Bao L, Yan Y, Xu C, Ji W, Shen S, Xu G et al (2013) MicroRNA-21 suppresses PTEN and hSulf-1 expression and promotes hepatocellular carcinoma progression through AKT/ERK pathways. Cancer Lett 337:226-236

65. Luo F, Ji J, Liu Y, Xu Y, Zheng G, Jing J et al (2014) MicroRNA-21, up-regulated by arsenite, directs the epithelial-mesenchymal transition and enhances the invasive potential of transformed human bronchial epithelial cells by targeting PDCD4. Toxicol Lett 232:301-309

66. Zhao J, Tang N, Wu K, Dai W, Ye C, Shi J et al (2014) MiR-21 simultaneously regulates ERK1 signaling in HSC activation and hepatocyte EMT in hepatic fibrosis. PLoS One 9:e108005

67. Zhang $Y$, Pan T, Zhong $X$, Cheng C (2014) Nicotine upregulates microRNA-21 and promotes TGF- $\beta$-dependent epithelial-mesenchymal transition of esophageal cancer cells. Tumour Biol 35:7063-7072

68. Duriez C, Falette N, Audoynaud C, Moyret-Lalle C, Bensaad K, Courtois S et al (2002) The human BTG2/TIS21/PC3 gene: genomic structure, transcriptional regulation and evaluation as a candidate tumor suppressor gene. Gene 282:207-214

69. Rouault JP, Falette N, Guéhenneux F, Guillot C, Rimokh R, Wang Q et al (1996) Identification of BTG2, an antiproliferative p53-dependent component of the DNA damage cellular response pathway. Nat Genet 14:482-486

70. Boiko AD, Porteous S, Razorenova OV, Krivokrysenko VI, Williams BR, Gudkov AV (2006) A systematic search for downstream mediators of tumor suppressor function of p53 reveals a major role of BTG2 in suppression of Ras-induced transformation. Genes Dev 20:236-252

71. Liu M, Wu H, Liu T, Li Y, Wang F, Wan H et al (2009) Regulation of the cell cycle gene, BTG2, by miR-21 in human laryngeal carcinoma. Cell Res 19:828-837

72. Yang CH, Yue J, Pfeffer SR, Fan M, Paulus E, Hosni-Ahmed A et al (2014) MicroRNA-21 promotes glioblastoma tumorigenesis by down-regulating insulin-like growth factor-binding protein-3 (IGFBP3). J Biol Chem 289:25079-25087
73. Martin JL, Baxter RC (2011) Signalling pathways of insulin-like growth factors (IGFs) and IGF binding protein-3. Growth Factors 29:235-244

74. Naspi A, Panasiti V, Abbate F, Roberti V, Devirgiliis V, Curzio M et al (2014) Insulin-like-growth-factor-binding-protein-3 (IGFBP-3) contrasts melanoma progression in vitro and in vivo. PLoS One 9:e98641

75. Yang CH, Pfeffer SR, Sims M, Yue J, Wang Y, Linga VG et al (2015) The oncogenic microRNA-21 inhibits the tumor suppressive activity of FBXO11 to promote tumorigenesis. J Biol Chem 290:6037-6046

76. Cardozo T, Pagano M (2004) The SCF ubiquitin ligase: insights into a molecular machine. Nat Rev Mol Cell Biol 5:739-751

77. Silverman JS, Skaar JR, Pagano M (2012) SCF ubiquitin ligases in the maintenance of genome stability. Trends Biochem Sci 37:66-73

78. Li Y, Chen F, Lin F, Guan C, Wei X, Wan Y et al (2009) VIT1/FBXO11 knockdown induces morphological alterations and apoptosis in B10BR mouse melanocytes. Int J Mol Med 23:673-678

79. Martin Del Campo SE, Latchana N, Levine KM, Grignol VP, Fairchild ET, Jaime-Ramirez AC et al (2015) MiR-21 enhances melanoma invasiveness via inhibition of tissue inhibitor of metalloproteinases 3 expression: in vivo effects of miR-21 inhibitor. PLoS One 10:e0115919

80. Qi JH, Ebrahem Q, Moore N, Murphy G, Claesson-Welsh L, Bond M et al (2003) A novel function for tissue inhibitor of metalloproteinases-3 (TIMP3): inhibition of angiogenesis by blockage of VEGF binding to VEGF receptor-2. Nat Med 9:407-415

81. Ahonen M, Ala-Aho R, Baker AH, George SJ, Grénman R, Saarialho-Kere U et al (2002) Antitumor activity and bystander effect of adenovirally delivered tissue inhibitor of metalloproteinases-3. Mol Ther 5:705-715

82. Ahonen M, Baker AH, Kähäri VM (1998) Adenovirus-mediated gene delivery of tissue inhibitor of metalloproteinases-3 inhibits invasion and induces apoptosis in melanoma cells. Cancer Res 58:2310-2315

83. Ahonen $M$, Poukkula M, Baker AH, Kashiwagi M, Nagase H, Eriksson JE et al (2003) Tissue inhibitor of metalloproteinases-3 induces apoptosis in melanoma cells by stabilization of death receptors. Oncogene 22:2121-2134

84. Ferraro A, Kontos CK, Boni T, Bantounas I, Siakouli D, Kosmidou V et al (2014) Epigenetic regulation of miR-21 in colorectal cancer: ITGB4 as a novel miR-21 target and a three-gene network (miR-21-ITGB4PDCD4) as predictor of metastatic tumor potential. Epigenetics 9:129-141

85. Yi YS, Baek KS, Cho JY (2014) L1 cell adhesion molecule induces melanoma cell motility by activation of mitogen-activated protein kinase pathways. Pharmazie 69:461-467

86. Doberstein K, Bretz NP, Schirmer U, Fiegl H, Blaheta R, Breunig C et al (2014) miR-21-3p is a positive regulator of L1CAM in several human carcinomas. Cancer Lett 354:455-466

87. Zhu S, Si ML, Wu H, Mo YY (2007) MicroRNA-21 targets the tumor suppressor gene tropomyosin 1 (TPM1). J Biol Chem 282:14328-14336

88. Okubo Y, Hamada J, Takahashi Y, Tada M, Tsutsumida A, Furuuchi K et al (2002) Transduction of HOXD3-antisense into human melanoma cells results in decreased invasive and motile activities. Clin Exp Metastasis 19:503-511

89. Liu S, Ren S, Howell P, Fodstad O, Riker Al (2008) Identification of novel epigenetically modified genes in human melanoma via promoter methylation gene profiling. Pigment Cell Melanoma Res. 21:545-555

90. Mellon I, Rajpal DK, Koi M, Boland CR, Champe GN (1996) Transcriptioncoupled repair deficiency and mutations in human mismatch repair genes. Science 272:557-560

91. de Wind N, Dekker M, Berns A, Radman M, te Riele H (1995) Inactivation of the mouse Msh2 gene results in mismatch repair deficiency, methylation tolerance, hyperrecombination, and predisposition to cancer. Cell 82:321-330

92. Pitsikas P, Lee D, Rainbow AJ (2007) Reduced host cell reactivation of oxidative DNA damage in human cells deficient in the mismatch repair gene hMSH2. Mutagenesis 22:235-243

93. Fishel R, Ewel A, Lee S, Lescoe MK, Griffith J (1994) Binding of mismatched microsatellite DNA sequences by the human MSH2 protein. Science 266:1403-1405

94. Hussein MR, Wood GS (2003) hMLH1 and hMSH2 gene mutations are present in radial growth-phase cutaneous malignant melanoma cell lines and can be induced further by ultraviolet-B irradiation. Exp Dermatol 12:872-875 
95. Korabiowska M, König F, Verheggen R, Schlott T, Cordon-Cardo C, Romeike B et al (2004) Altered expression and new mutations in DNA mismatch repair genes $\mathrm{MLH1}$ and $\mathrm{MSH} 2$ in melanoma brain metastases. Anticancer Res 24:981-986

96. Korabiowska M, Brinck U, Stachura J, Korabiowska M, Brinck U, Stachura $J$ et al (2006) Exonic deletions of mismatch repair genes MLH1 and $\mathrm{MSH} 2$ correlate with prognosis and protein expression levels in malignant melanomas. Anticancer Res 26:1231-1235

97. Korabiowska M, Dengler H, Kellner S, Stachura J, Schauer A (1997) Decreased expression of MLH1, MSH2, PMS1 and PMS2 in pigmented lesions indicates accumulation of failed DNA repair along with malignant transformation and tumour progression. Oncol Rep 4:653-655

98. Bhandari A, Gordon W, Dizon D, Hopkin AS, Gordon E, Yu Z et al (2013) The Grainyhead transcription factor Grhl3/Get1 suppresses miR-21 expression and tumorigenesis in skin: modulation of the miR-21 target MSH2 by RNA-binding protein DND1. Oncogene 32:1497-1507

99. Heidenreich B, Rachakonda PS, Hemminki K, Kumar R (2014) TERT promoter mutations in cancer development. Curr Opin Genet Dev 24:30-37

100. Diaz A, Puig-Butillé JA, Muñoz C, Costa D, Díez A, Garcia-Herrera A et al (2014) TERT gene amplification is associated with poor outcome in acral lentiginous melanoma. J Am Acad Dermatol 71:839-841

101. Llorca-Cardeñosa MJ, Peña-Chilet M, Mayor M, Gomez-Fernandez C, Casado B, Martin-Gonzalez M et al (2014) Long telomere length and a TERT-CLPTM1 locus polymorphism association with melanoma risk. Eur J Cancer 50:3168-3177

102. Vagner J, Steiniche T, Stougaard M (2015) In-situ hybridization-based quantification of hTR: a possible biomarker in malignant melanoma. Histopathology 66:747-751

103. Wang YY, Sun G, Luo H, Wang XF, Lan FM, Yue X et al (2012) MiR-21 modulates hTERT through a STAT3-dependent manner on glioblastoma cell growth. CNS Neurosci Ther 18:722-728

104. Sarkar D, Leung EY, Baguley BC, Finlay GJ, Askarian-Amiri ME (2015) Epigenetic regulation in human melanoma: past and future. Epigenetics 10:103-121

105. Kappelmann M, Bosserhoff A, Kuphal S (2014) AP-1/C-Jun transcription factors: regulation and function in malignant melanoma. Eur J Cell Biol 93:76-81

106. Fujita S, Ito T, Mizutani T, Minoguchi S, Yamamichi N, Sakurai K et al (2008) miR-21 gene expression triggered by AP-1 is sustained through a double-negative feedback mechanism. J Mol Biol 378:492-504

107. Echevarría-Vargas IM, Valiyeva F, Vivas-Mejía PE (2014) Upregulation of miR-21 in cisplatin resistant ovarian cancer via JNK-1/c-Jun pathway. PLoS One 9:e97094

108. Chen L, Bourguignon LY (2014) Hyaluronan-CD44 interaction promotes c-Jun signaling and miRNA21 expression leading to BCl-2 expression and chemoresistance in breast cancer cells. Mol Cancer 13:52

109. Misawa A, Katayama R, Koike S, Tomida A, Watanabe T, Fujita N (2010) AP-1-dependent miR-21 expression contributes to chemoresistance in cancer stem cell-like SP cells. Oncol Res 19:23-33

110. Jalili A, Wagner C, Pashenkov M, Pathria G, Mertz KD, Widlund HR et al (2012) Dual suppression of the cyclin-dependent kinase inhibitors CDKN2C and CDKN1A in human melanoma. J Natl Cancer Inst 104:1673-1679

111. Landgraf $P$, Rusu M, Sheridan R, Sewer A, lovino N, Aravin A et al (2007) A mammalian microRNA expression atlas based on small RNA library sequencing. Cell 129:1401-1414

112. Talotta F, Cimmino A, Matarazzo MR, Casalino L, De Vita G, D'Esposito $\mathrm{M}$ et al (2009) An autoregulatory loop mediated by miR-21 and PDCD4 controls the AP- 1 activity in RAS transformation. Oncogene 28:73-84

113. Kappelmann M, Kuphal S, Meister G, Vardimon L, Bosserhoff AK (2013) MicroRNA miR-125b controls melanoma progression by direct regulation of C-Jun protein expression. Oncogene 32:2984-2991

114. Niu G, Bowman T, Huang M, Shivers S, Reintgen D, Daud A et al (2002) Roles of activated Src and Stat3 signaling in melanoma tumor cell growth. Oncogene 21:7001-7010

115. Yang CH, Fan M, Slominski AT, Yue J, Pfeffer LM (2010) The role of constitutively activated STAT3 in B16 melanoma cells. Int J Infereron Cytokine Mediator Res 2010:1-7
116. Ou H, Li Y, Kang M (2014) Activation of miR-21 by STAT3 induces proliferation and suppresses apoptosis in nasopharyngeal carcinoma by targeting PTEN gene. PLoS One 9:e109929

117. Kortylewski M, Jove R, Yu H (2005) Targeting STAT3 affects melanoma on multiple fronts. Cancer Metastasis Rev 24:315-327

118. Becker TM, Boyd SC, Mijatov B, Gowrishankar K, Snoyman S, Pupo GM et al (2014) Mutant B-RAF-Mcl-1 survival signaling depends on the STAT3 transcription factor. Oncogene 33:1158-1166

119. Fedorenko IV, Fang B, Munko AC, Gibney GT, Koomen JM, Smalley KS (2015) Phosphoproteomic analysis of basal and therapy-induced adaptive signaling networks in BRAF and NRAS mutant melanoma. Proteomics 15:327-339

120. Segura MF, Hanniford D, Menendez S, Reavie L, Zou X, Alvarez-Diaz S et al (2009) Aberrant miR-182 expression promotes melanoma metastasis by repressing $\mathrm{FOXO} 3$ and microphthalmia-associated transcription factor. Proc Natl Acad Sci USA 106:1814-1819

121. Liu S, Howell PM, Riker Al (2013) Up-regulation of miR-182 expression after epigenetic modulation of human melanoma cells. Ann Surg Oncol 20:1745-1752

122. Fabbri M, Calin GA (2010) Epigenetics and miRNAs in human cancer. Adv Genet 70:87-99

123. Iorio MV, Piovan C, Croce CM (2010) Interplay between microRNAs and the epigenetic machinery: an intricate network. Biochim Biophys Acta 1799:694-701

124. Babacan A, Lebe B (2012) Grade of atypia in dysplastic nevi and relationship with dermal fibroplasia. Turk Patoloji Derg 28:17-23

125. Kazlouskaya V, Malhotra S, Navarro R, Wu KN, Shvartsbeyn M, Shengli C et al (2013) Dermal changes in superficial basal cell carcinoma, melanoma in situ and actinic keratosis and their implications. J Cutan Pathol 40:1014-1020

126. Babalola O, Mamalis A, Lev-Tov H, Jagdeo J (2013) The role of microRNAs in skin fibrosis. Arch Dermatol Res 305:763-776

127. Brønnum $H$, Andersen DC, Schneider M, Sandberg MB, Eskildsen T, Nielsen SB et al (2013) miR-21 promotes fibrogenic epithelial-to-mesenchymal transition of epicardial mesothelial cells involving Programmed Cell Death 4 and Sprouty-1. PLoS One 8:e56280

128. Huang Y, He Y, Li J (2015) Microrna-21: a central regulator of fibrotic diseases via various targets. Curr Pharm Des 21:2236-2242

129. Zhang J, Jiao J, Cermelli S, Muir K, Jung KH, Zou R et al (2015) miR21 inhibition reduces liver fibrosis and prevents tumor development by inducing apoptosis of CD24+ progenitor cells. Cancer Res 75:1859-1867

130. Anderberg C, Li H, Fredriksson L, Andrae J, Betsholtz C, Li X et al (2009) Paracrine signaling by platelet-derived growth factor-CC promotes tumor growth by recruitment of cancer-associated fibroblasts. Cancer Res 69:369-378

131. Li Q, Zhang D, Wang Y, Sun P, Hou X, Larner J et al (2013) MiR-21/Smad 7 signaling determines TGF- $\beta$ 1-induced CAF formation. Sci Rep 3:2038

132. Zaidi MR, De Fabo EC, Noonan FP, Merlino G (2012) Shedding light on melanocyte pathobiology in vivo. Cancer Res 72:1591-1595

133. Leiter U, Eigentler T, Garbe C (2014) Epidemiology of skin cancer. Adv Exp Med Biol 810:120-140

134. Noonan FP, Zaidi MR, Wolnicka-Glubisz A, Anver MR, Bahn J, Wielgus A et al (2012) Melanoma induction by ultraviolet A but not ultraviolet B radiation requires melanin pigment. Nat Commun 3:884

135. Yoshizumi M, Nakamura T, Kato M, Ishioka T, Kozawa K, Wakamatsu K et al (2008) Release of cytokines/chemokines and cell death in UVBirradiated human keratinocytes, HaCaT. Cell Biol Int 32:1405-1411

136. Eberlein-König B, Jäger C, Przybilla B (1998) Ultraviolet B radiationinduced production of interleukin 1alpha and interleukin 6 in a human squamous carcinoma cell line is wavelength-dependent and can be inhibited by pharmacological agents. Br J Dermatol 139:415-421

137. Hirano T, Ishihara K, Hibi M (2000) Roles of STAT3 in mediating the cell growth, differentiation and survival signals relayed through the IL-6 family of cytokine receptors. Oncogene 19:2548-2556

138. Nilsen LT, Aalerud TN, Hannevik M, Veierød MB (2012) High UV-A exposure from sunbeds. Pigment Cell Melanoma Res 25:639-640

139. Moan JE, Baturaite Z, Dahlback A, Porojnicu AC (2014) Ultraviolet radiation and cutaneous malignant melanoma. Adv Exp Med Biol 810:359-374 
140. Sanlorenzo M, Wehner MR, Linos E, Kornak J, Kainz W, Posch C et al (2015) The risk of melanoma in airline pilots and cabin crew: a metaanalysis. JAMA Dermatol 151:51-58

141. Sanlorenzo M, Vujic I, Posch C, Cleaver JE, Quaglino P, Ortiz-Urda S (2015) The risk of melanoma in pilots and cabin crew: UV measurements in flying airplanes. JAMA Dermatol 151:450-452

142. Lall RK, Mukhtar H, Syed DN (2015) MicroRNAs and photocarcinogenesis. Photochem Photobiol 91:173-187

143. Syed DN, Afaq F, Mukhtar H (2012) Differential activation of signaling pathways by UVA and UVB radiation in normal human epidermal keratinocytes. Photochem Photobiol 88:1184-1190

144. Hou L, Bowman L, Meighan TG, Pratheeshkumar P, Shi X, Ding M (2013) Induction of miR-21-PDCD4 signaling by UVB in JB6 cells involves ROSmediated MAPK pathways. Exp Toxicol Pathol 65:1145-1148

145. Xu S, Ding N, Pei $\mathrm{H}$ et al (2015) MiR-21 is involved in radiation-induced bystander effects. RNA Biol 11:1161-1170

146. Chaudhry MA, Omaruddin RA (2012) Differential regulation of microRNA expression in irradiated and bystander cells. Mol Biol (Mosk) 46:634-643

147. Chaudhry MA, Sachdeva H, Omaruddin RA (2010) Radiation-induced micro-RNA modulation in glioblastoma cells differing in DNA-repair pathways. DNA Cell Biol 29:553-561

148. Record M, Subra C, Silvente-Poirot S, Poirot M (2011) Exosomes as intercellular signalosomes and pharmacological effectors. Biochem Pharmacol 81:1171-1182

149. Colombo M, Raposo G, Théry C (2014) Biogenesis, secretion, and intercellular interactions of exosomes and other extracellular vesicles. Annu Rev Cell Dev Biol 30:255-289

150. Dahle J, Kvam E, Stokke T (2005) Bystander effects in UV-induced genomic instability: antioxidants inhibit delayed mutagenesis induced by ultraviolet $A$ and $B$ radiation. J Carcinog 4:11

151. Whiteside JR, McMillan TJ (2009) A bystander effect is induced in human cells treated with UVA radiation but not UVB radiation. Radiat Res 171:204-211

152. Ghosh R, Guha D, Bhowmik S, Karmakar S (2013) Antioxidant enzymes and the mechanism of the bystander effect induced by ultraviolet $C$ irradiation of A375 human melanoma cells. Mutat Res 757:83-90

153. Widel M, Krzywon A, Gajda K, Skonieczna M, Rzeszowska-Wolny J (2014) Induction of bystander effects by UVA, UVB, and UVC radiation in human fibroblasts and the implication of reactive oxygen species. Free Radic Biol Med 68:278-287

154. Agredano YZ, Chan JL, Kimball RC, Kimball AB (2006) Accessibility to air travel correlates strongly with increasing melanoma incidence. Melanoma Res 16:77-81

155. Hallberg O, Johansson O (2004) Malignant melanoma of the skin — not a sunshine story! Med Sci Monit 10:CR336-CR340

156. Lu Y, He M, Zhang Y, Xu S, Zhang L, He Y et al (2014) Differential proinflammatory responses of astrocytes and microglia involve STAT3 activation in response to $1800 \mathrm{MHz}$ radiofrequency fields. PLoS One 9:e108318

157. Scarbrough PM, Akushevich I, Wrensch M, II'yasova D (2014) Exploring the association between melanoma and glioma risks. Ann Epidemiol 24:469-474

158. Dupin E, Sommer $L$ (2012) Neural crest progenitors and stem cells: from early development to adulthood. Dev Biol 366:83-95

159. Akhavan-Sigari R, Baf MM, Ariabod V, Rohde V, Rahighi S (2014) Connection between cell phone use, p53 gene expression in different zones of glioblastoma multiforme and survival prognoses. Rare Tumors 6:5350

160. Shang C, Guo Y, Hong Y, Liu YH, Xue YX (2015) MiR-21 up-regulation mediates glioblastoma cancer stem cells apoptosis and proliferation by targeting FASLG. Mol Biol Rep 42:721-727

161. International Agency for Research on Cancer, WHO, Press Release No. 208, 31 May, 2011: http://www.iarc.fr/en/media-centre/pr/2011/pdfs/ pr208_E.pdf

162. Reinhardt TA, Lippolis JD, Nonnecke BJ, Sacco RE (2012) Bovine milk exosome proteome. J Proteomics 75:1486-1492

163. Izumi H, Kosaka N, Shimizu T, Sekine K, Ochiya T, Takase M (2013) Purification of RNA from milk whey. Methods Mol Biol 1024:191-201

164. Sun Q, Chen X, Yu J, Zen K, Zhang CY, Li L (2013) Immune modulatory function of abundant immune-related microRNAs in microvesicles from bovine colostrum. Protein Cell 4:197-210
165. Howard KM, Jati Kusuma R, Baier SR, Friemel T, Markham L, Vanamala J et al (2015) Loss of miRNAs during processing and storage of cow's (Bos taurus) milk. J Agric Food Chem 63:588-592

166. Chen X, Liang H, Zhang J, Zen K, Zhang CY (2012) Secreted microRNAs: a new form of intercellular communication. Trends Cell Biol 22:125-132

167. Chen X, Gao C, Li H, Huang L, Sun Q, Dong Y et al (2010) Identification and characterization of microRNAs in raw milk during different periods of lactation, commercial fluid, and powdered milk products. Cell Res 20:1128-1137

168. Pieters BC, Arntz OJ, Bennink MB, Broeren MG, van Caam AP, Koenders $\mathrm{Ml}$ et al (2015) Commercial cow milk contains physically stable extracellular vesicles expressing immunoregulatory TGF- $\beta$. PLoS One 10:e0121123

169. Duarte-Salles T, Fedirko V, Stepien M, Duarte-Salles T, Fedirko V, Stepien et al (2014) Dairy products and risk of hepatocellular carcinoma: the European Prospective Investigation into Cancer and Nutrition. Int J Cancer 135:1662-1672

170. Löffler D, Brocke-Heidrich K, Pfeifer G, Stocsits C, Hackermüller J, Kretzschmar AK et al (2007) Interleukin-6 dependent survival of multiple myeloma cells involves the Stat3-mediated induction of microRNA-21 through a highly conserved enhancer. Blood 110:1330-1333

171. Michaëlsson K, Wolk A, Langenskiöld S, Basu S, Warensjö Lemming E, Melhus $\mathrm{H}$ et al (2014) Milk intake and risk of mortality and fractures in women and men: cohort studies. BMJ 349:96015

172. von Felbert V, Córdoba F, Weissenberger J, Vallan C, Kato M, Nakashima et al (2005) Interleukin-6 gene ablation in a transgenic mouse model of malignant skin melanoma. Am J Pathol 166:411-831

173. Hoejberg L, Bastholt L, Schmidt H (2012) Interleukin-6 and melanoma. Melanoma Res 22:327-333

174. Cao Q, Li YY, He WF, Zhang ZZ, Zhou Q, Liu X et al (2013) Interplay between microRNAs and the STAT3 signaling pathway in human cancers. Physiol Genomics 45:1206-1214

175. Huang C, Li H, Wu W, Jiang T, Qiu Z (2013) Regulation of miR-155 affects pancreatic cancer cell invasiveness and migration by modulating the STAT3 signaling pathway through SOCS1. Oncol Rep 30:1223-1230

176. Zhao XD, Zhang W, Liang HJ, Ji WY (2013) Overexpression of miR-155 promotes proliferation and invasion of human laryngeal squamous cell carcinoma via targeting SOCS1 and STAT3. PLoS One 8:e56395

177. Davis BN, Hilyard AC, Lagna G, Hata A (2008) SMAD proteins control DROSHA- mediated microRNA maturation. Nature 454:56-61

178. Taylor DD, Gercel-Taylor C (2008) MicroRNA signatures of tumor-derived exosomes as diagnostic biomarkers of ovarian cancer. Gynecol Oncol 110:13-21

179. Skog J, Würdinger T, van Rijn S, Meijer DH, Gainche L, Sena-Esteves M et al (2008) Glioblastoma microvesicles transport RNA and protein that promote tumor growth and provide diagnostic biomarkers. Nat Cell Biol 10:1470-1476

180. Tian T, Zhu YL, Zhou YY, Liang GF, Wang YY, Hu FH et al (2014) Exosome uptake through clathrin-mediated endocytosis and macropinocytosis and mediating miR-21 delivery. J Biol Chem 289:22258-22267

181. Xiao D, Ohlendorf J, Chen Y, Taylor DD, Rai SN, Waigel S et al (2012) Identifying mRNA, microRNA and protein profiles of melanoma exosomes. PLoS One 7:e46874

182. Gajos-Michniewicz A, Duechler M, Czyz M (2014) MiRNA in melanomaderived exosomes. Cancer Lett 347:29-37

183. Cereghetti DM, Lee PP (2014) Tumor-derived exosomes contain microRNAs with immunological Function: implications for a Novel Immunosuppression Mechanism. Microrna 2:194-204

184. Miao BP, Zhang RS, Li M, Fu YT, Zhao M, Liu ZG et al (2014) Nasopharyngeal cancer-derived microRNA-21 promotes immune suppressive B cells. Cell Mol Immunol [Epub ahead of print]

185. McClure C, Brudecki L, Ferguson DA, Yao ZQ, Moorman JP, McCall CE et al (2014) MicroRNA 21 (miR-21) and miR-181b couple with NFI-A to generate myeloid- derived suppressor cells and promote immunosuppression in late sepsis. Infect Immun 82:3816-3825

186. Chevolet I, Speeckaert R, Schreuer M, Neyns B, Krysko O, Bachert C et al (2015) Clinical significance of plasmacytoid dendritic cells and myeloidderived suppressor cells in melanoma. J Transl Med 13:9

187. Chen Y, Chen J, Wang H, Shi J, Wu K, Liu S et al (2013) HCV-induced miR21 contributes to evasion of host immune system by targeting MyD88 and IRAK1. PLoS Pathog 9:e1003248 
188. Fabbri M, Paone A, Calore F, Galli R, Gaudio E, Santhanam R et al (2012) MicroRNAs bind to Toll-like receptors to induce prometastatic inflammatory response. Proc Natl Acad Sci USA 109:E2110-E2116

189. Olivieri F, Spazzafumo L, Santini G, Lazzarini R, Albertini MC, Rippo MR et al (2012) Age-related differences in the expression of circulating microRNAs: miR-21 as a new circulating marker of inflammaging. Mech Ageing Dev 133:675-685

190. Cheng Y, Zhang C (2010) MicroRNA-21 in cardiovascular disease. J Cardiovasc Transl Res 3:251-255

191. Hulsmans M, Holvoet P (2013) MicroRNA-containing microvesicles regulating inflammation in association with atherosclerotic diesease. Cardiovasc Res 100:7-18

192. Iliopoulos D, Jaeger SA, Hirsch HA, Bulyk ML, Struhl K (2010) STAT3 activation of miR-21 and miR-181b-1 via PTEN and CYLD are part of the epigenetic switch linking inflammation to cancer. Mol Cell 39:493-506

193. Schneider SL, Ross AL, Grichnik JM (2015) Do inflammatory pathways drive melanomagenesis? Exp Dermatol 24:86-90

194. Jiang H, Gebhardt C, Umansky L, Beckhove P, Schulze TJ, Utikal J, Umansky V (2014) Elevated chronic inflammatory factors and myeloid-derived suppressor cells indicate poor prognosis in advanced melanoma patients. Int J Cancer [Epub ahead of print]

195. Romay MC, Che N, Becker SN, Pouldar D, Hagopian R, Xiao X et al (2015) Regulation of NF-KB signaling by oxidized glycerophospholipid and $\mathrm{IL}-1 \beta$ induced miRs-21-3p and $-27 \mathrm{a}-5 \mathrm{p}$ in human aortic endothelial cells. J Lipid Res 1556:38-50

196. Xia Y, Khoi PN, Yoon HJ, Lian S, Joo YE, Chay KO et al (2015) Piperine inhibits IL-1 $\beta$-induced IL-6 expression by suppressing p38 MAPK and STAT3 activation in gastric cancer cells. Mol Cell Biochem 398:147-156

197. Diakos Cl, Charles KA, McMillan DC, Clarke SJ (2014) Cancer-related inflammation and treatment effectiveness. Lancet Oncol 15:e493-e503

198. Sheedy FJ (2015) Turning 21: induction of miR-21 as a key switch in the inflammatory response. Front Immunol 6:19

199. Ruan Q, Wang P, Wang T, Qi J, Wei M, Wang S et al (2014) MicroRNA-21 regulates $T$-cell apoptosis by directly targeting the tumor suppressor gene Tipe2. Cell Death Dis 5:e1095

200. Sun H, Gong S, Carmody RJ, Hilliard A, Li L, Sun J et al (2008) TIPE2, a negative regulator of innate and adaptive immunity that maintains immune homeostasis. Cell 133:415-426

201. Lou Y, Zhang G, Geng M, Zhang W, Cui J, Liu S (2014) TIPE2 negatively regulates inflammation by switching arginine metabolism from nitric oxide synthase to arginase. PLoS One 9:e96508

202. Long Y, Tsai WB, Wangpaichitr M, Tsukamoto T, Savaraj N, Feun LG et al (2013) Arginine deiminase resistance in melanoma cells is associated with metabolic reprogramming, glucose dependence, and glutamine addiction. Mol Cancer Ther 12:2581-2590

203. Sun H, Zhuang G, Chai L, Wang Z, Johnson D, Ma Y et al (2012) TIPE2 controls innate immunity to RNA by targeting the phosphatidylinositol 3-kinase-Rac pathway. J Immunol 189:2768-2773

204. Zhang $Y H$, Yan HQ, Wang F, Wang $Y Y$, Jiang $Y N$, Wang $Y N$ et al (2015) TIPE2 inhibits TNF- $\alpha$-induced hepatocellular carcinoma cell metastasis via Erk1/2 downregulation and NF-kB activation. Int J Oncol 46:254-264

205. Li Y, Li X, Liu G, Sun R, Wang L, Wang J et al (2015) Downregulated TIPE2 is associated with poor prognosis and promotes cell proliferation in non-small ell lung cancer. Biochem Biophys Res Commun 457:43-49

206. Lou Y, Liu S (2011) The TIPE (TNFAIP8) family in inflammation, immunity, and cancer. Mol Immunol 49:4-7

207. Gus-Brautbar Y, Johnson D, Zhang L, Sun H, Wang P, Zhang S et al (2012) The anti-inflammatory TIPE2 is an inhibitor of the oncogenic Ras. Mol Cell 45:610-618

208. Bray GA, Popkin BM (2014) Dietary sugar and body weight: have we reached a crisis in the epidemic of obesity and diabetes?: health be damned! Pour on the sugar. Diabetes Care 37:950-956

209. Shang YY, Fang NN, Wang F, Wang H, Wang ZH, Tang MX et al (2015) MicroRNA- 21, induced by high glucose, modulates macrophage apoptosis via programmed cell death 4. Mol Med Rep 12:463-469

210. Kang M, Yan LM, Zhang WY, Li YM, Tang AZ, Ou HS (2013) Role of microRNA-21 in regulating 3T3-L1 adipocyte differentiation and adiponectin expression. Mol Biol Rep 40:5027-5034
211. Keller P, Gburcik V, Petrovic N, Gallagher IJ, Nedergaard J, Cannon B et al (2011) Gene-chip studies of adipogenesis-regulated microRNAs in mouse primary adipocytes and human obesity. BMC Endocr Disord 11:7

212. Chartoumpekis DV, Zaravinos A, Ziros PG, Iskrenova RP, Psyrogiannis Al, Kyriazopoulou VE et al (2012) Differential expression of microRNAs in adipose issue after long-term high-fat diet-induced obesity in mice. PLoS One 7:e34872

213. Seeger T, Fischer A, Muhly-Reinholz M, Zeiher AM, Dimmeler S (2014) Long-term inhibition of miR-21 leads to reduction of obesity in $\mathrm{db} / \mathrm{db}$ mice. Obesity (Silver Spring) 22:2352-2360

214. Pandey V, Vijayakumar MV, Ajay AK, Malvi P, Bhat MK (2012) Diet-induced obesity increases melanoma progression: involvement of Cav-1 and FASN. Int J Cancer 130:497-508

215. Malvi P, Chaube B, Pandey V, Vijayakumar MV, Boreddy PR, Mohammad $\mathrm{N}$ et al (2015) Obesity induced rapid melanoma progression is reversed by orlistat treatment and dietary intervention: role of adipokines. Mol Oncol 9:689-703

216. Müller G, Schneider M, Biemer-Daub G, Wied S (2011) Microvesicles released from rat adipocytes and harboring glycosylphosphatidylinositol-anchored proteins transfer RNA stimulating lipid synthesis. Cell Signal 23:1207-1223

217. Ferrante SC, Nadler EP, Pillai DK, Hubal MJ, Wang Z, Wang JM et al (2015) Adipocyte-derived exosomal miRNAs: a novel mechanism for obesityrelated disease. Pediatr Res 77:447-454

218. Jung J, Cho HJ, Jung YJ, Kwon SH, Her S, Choi SS et al (2015) High-fat diet- induced obesity increases lymphangiogenesis and lymph node metastasis in the B16F10 melanoma allograft model: roles of adipocytes and M2- macrophages. Int J Cancer 136:258-270

219. Chi M, Chen J, Ye Y, Tseng HY, Lai F, Tay KH et al (2014) Adipocytes contribute to resistance of human melanoma cells to chemotherapy and targeted therapy. Curr Med Chem 21:1255-1267

220. Xu L, Huang Y, Chen D, He J, Zhu W, Zhang Y et al (2014) Downregulation of miR- 21 increases cisplatin sensitivity of non-small-cell lung cancer. Cancer Genet 207:214-220

221. Zhou X, Ren Y, Liu A, Jin R, Jiang Q, Huang Y et al (2014) WP1066 sensitizes oral squamous cell carcinoma cells to cisplatin by targeting STAT3/ miR-21 axis. Sci Rep 4:7461

222. Zhang HL, Yang LF, Zhu Y, Yao XD, Zhang SL, Dai B et al (2011) Serum miRNA- 21: elevated levels in patients with metastatic hormone-refractory prostate cancer and potential predictive factor for the efficacy of docetaxel-based chemotherapy. Prostate 71:326-331

223. Shi GH, Ye DW, Yao XD, Zhang SL, Dai B, Zhang HL et al (2010) Involvement of microRNA-21 in mediating chemo-resistance to docetaxel in androgen- independent prostate cancer PC3 cells. Acta Pharmacol Sin 31:867-873

224. Murzaku EC, BronsnickT, Rao BK (2014) Diet in dermatology: Part II. Melanoma, chronic urticaria, and psoriasis. J Am Acad Dermatol 71:1053. e1-1053.e16

225. Bagnardi V, Rota M, Botteri E, Tramacere I, Islami F, Fedirko V et al (2015) Alcohol consumption and site-specific cancer risk: a comprehensive dose-response meta-analysis. Br J Cancer 112:580-593

226. Beech RD, Leffert JJ, Lin A, Hong KA, Hansen J, Umlauf S et al (2014) Stress- related alcohol consumption in heavy drinkers correlates with expression of miR-10a, miR-21, and components of the TARRNA-binding protein- associated complex. Alcohol Clin Exp Res 38:2743-2753

227. Shors AR, Solomon C, McTiernan A, White E (2001) Melanoma risk in relation to height, weight, and exercise (United States). Cancer Causes Control 12:599-606

228. Gogas H, Trakatelli M, Dessypris N, Terzidis A, Katsambas A, Chrousos GP et al (2008) Melanoma risk in association with serum leptin levels and lifestyle parameters: a case-control study. Ann Oncol 19:384-389

229. Nielsen S, Åkerström T, Rinnov A, Yfanti C, Scheele C, Pedersen BK et al (2014) The miRNA plasma signature in response to acute aerobic exercise and endurance training. PLoS One 9:e87308 
230. Stánitz E, Juhász K, Tóth C, Gombos K, Natali PG, Ember I (2013) Evaluation of MicroRNA expression pattern of gastric adenocarcinoma associated with socioeconomic, environmental and lifestyle factors in northwestern Hungary. Anticancer Res 33:3195-3200

231. Cooper KL, Yager JW, Hudson LG (2014) Melanocytes and keratinocytes have distinct and shared responses to ultraviolet radiation and arsenic. Toxicol Lett 224:407-415

232. Kong AP, Xiao K, Choi KC, Wang G, Chan MH, Ho CS et al (2012) Associations between microRNA (miR-21, 126, 155 and 221), albuminuria and heavy metals in Hong Kong Chinese adolescents. Clin Chim Acta 413:1053-1057

233. Li X, Shi Y, Wei Y, Li X, Shi Y, Wei Y (2012) Altered expression profiles of microRNAs upon arsenic exposure of human umbilical vein endothelial cells. Environ Toxicol Pharmacol 34:381-387

234. Sturchio E, Colombo T, Boccia P, Carucci N, Meconi C, Minoia C et al (2014) Arsenic exposure triggers a shift in microRNA expression. Sci Total Environ 472:672-680

235. Sun J, Yu M, Lu Y, Thakur C, Chen B, Qiu P et al (2014) Carcinogenic metalloid arsenic induces expression of mdig oncogene through JNK and STAT3 activation. Cancer Lett 346:257-263

236. Xu Y, Luo F, Liu Y, Shi L, Lu X, Xu W et al (2014) Exosomal miR-21 derived from arsenite-transformed human bronchial epithelial cells promotes cell proliferation associated with arsenite carcinogenesis. Arch Toxicol [Epub ahead of print]

237. Bollati V, Marinelli B, Apostoli P, Bonzini M, Nordio F, Hoxha M et al (2010) Exposure to metal-rich particulate matter modifies the expression of candidate microRNAs in peripheral blood leukocytes. Environ Health Perspect 118:763-768

238. Yamamoto M, Singh A, Sava F, Pui M, Tebbutt SJ, Carlsten C (2013) MicroRNA expression in response to controlled exposure to diesel exhaust: attenuation by the antioxidant $\mathrm{N}$-acetylcysteine in a randomized crossover study. Environ Health Perspect 121:670-675

239. Xiao L, Kaneyasu K, Saitoh Y, Terashima Y, Kowata Y, Miwa N (2009) Cytoprotective effects of the lipoidic-liquiform pro-vitamin $C$ tetra-isopalmitoyl- ascorbate (VC-IP) against ultraviolet-A ray-induced injuries in human skin cells together with collagen retention, MMP inhibition and p53 gene repression. J Cell Biochem 106:589-598

240. Murtas D, Piras F, Minerba L, Ugalde J, Floris C, Maxia C et al (2010) Nuclear 8- hydroxy-2'-deoxyguanosine as survival biomarker in patients with cutaneous melanoma. Oncol Rep 23:329-335

241. Box NF, Terzian T (2008) The role of p53 in pigmentation, tanning and melanoma. Pigment Cell Melanoma Res 21:525-533

242. Nihal M, Roelke CT, Wood GS (2010) Anti-melanoma effects of vorinostat in combination with polyphenolic antioxidant (-)-epigallocatechin-3-gallate (EGCG). Pharm Res 27:1103-1114

243. da Cruz AT, Jasiulionis MG (2012) miRNAs and melanoma: how are they connected? Dermatol Res Pract 2012:528345
244. Hanahan D, Weinberg RA (2011) Hallmarks of cancer: the next generation. Cell 144:646-674

245. Camussi G, Deregibus MC, Bruno S, Grange C, Fonsato V, Tetta C (2011) Exosome/microvesicle-mediated epigenetic reprogramming of cells. Am J Cancer Res 1:98-110

246. Benito-Martin A, Di Giannatale A, Ceder S, Peinado H (2015) The new deal: a potential role for secreted vesicles in innate immunity and tumor progression. Front Immunol 24(6):66

247. Mione M, Bosserhoff A (2015) MicroRNAs in melanocyte and melanoma biology. Pigment Cell Melanoma Res 28:340-354

248. Giunti L, da Ros M, Vinci S, Gelmini S, lorio AL, Buccoliero AM et al (2014) Anti- miR21 oligonucleotide enhances chemosensitivity of T98G cell line to doxorubicin by inducing apoptosis. Am J Cancer Res 5:231-242

249. Chan JK, Blansit K, Kiet T, Sherman A, Wong G, Earle C et al (2014) The inhibition of miR-21 promotes apoptosis and chemosensitivity in ovarian cancer. Gynecol Oncol 132:739-744

250. Yang CH, Yue J, Sims M, Pfeffer LM (2013) The curcumin analog EF24 targets NF- $\kappa$ B and miRNA-21, and has potent anticancer activity in vitro and in vivo. PLoS One 8:e71130

251. Jacobson MD, Burne JF, King MP, Miyashita T, Reed JC, Raff MC (1993) $\mathrm{BCl}-2$ blocks apoptosis in cells lacking mitochondrial DNA. Nature 361:365-369

252. Cheli Y, Ohanna M, Ballotti R, Bertolotto C (2010) Fifteen-year quest for microphthalmia-associated transcription factor target genes. Pigment Cell Melanoma Res 23:27-40

253. McGill GG, Horstmann M, Widlund HR, Du J, Motyckova G, Nishimura EK et al (2002) Bcl2 regulation by the melanocyte master regulator Mitf modulates lineage survival and melanoma cell viability. Cell 109:707-718

254. Watanabe M, Umezawa K, Higashihara M, Horie R (2013) Combined inhibition of $\mathrm{NF}-\mathrm{kB}$ and $\mathrm{BCl}-2$ triggers synergistic reduction of viability and induces apoptosis in melanoma cells. Oncol Res 21:173-180

255. Li Y, Yan L, Zhang W, Wang H, Chen W, Hu N et al (2014) miR-21 inhibitor suppresses proliferation and migration of nasopharyngeal carcinoma cells through down-regulation of BCL2 expression. Int J Clin Exp Pathol 7:3478-3487

256. Si ML, Zhu S, Wu H, Lu Z, Wu F, Mo YY (2007) miR-21-mediated tumor growth. Oncogene 26:2799-2803

257. Chen B, Chen X, Wu X, Wang X, Wang Y, Lin TY et al (2015) Disruption of microRNA-21 by TALEN leads to diminished cell transformation and increased expression of cell-environment interaction genes. Cancer Lett 356:506-516

258. Bordelon JA, Sanchez MI, Grichnik JM (2015) Melanomagenesis: multifaceted attacks on the genome. Exp Dermatol 24:175-176

259. Ajit SK (2012) Circulating microRNAs as biomarkers, therapeutic targets, and signaling molecules. Sensors (Basel) 12:3359-3369

\section{Submit your next manuscript to BioMed Central and take full advantage of:}

- Convenient online submission

- Thorough peer review

- No space constraints or color figure charges

- Immediate publication on acceptance

- Inclusion in PubMed, CAS, Scopus and Google Scholar

- Research which is freely available for redistribution

Submit your manuscript at

www.biomedcentral.com/submit

C Biomed Central 